\title{
Xanthine: Synthetic Strategy And Biological Activity
}

\author{
Kavita Yadav ${ }^{1}$, Divya Yadav ${ }^{2}$, Rakesh Yadav ${ }^{3, *}$ (DD \\ 1 Department of Chemistry, Banasthali Vidyapith, Banasthali-304022, Rajasthan; kvt.yadav@gmail.com (K.Y.); \\ 2 Department of Pharmacy, Banasthali Vidyapith, Banasthali-304022, Rajasthan; divyavirgo2002@gmail.com (D.Y.); \\ 3 Amity Institute of Pharmacy, Amity University, Manesar-122413, Haryana; rakesh_pu@yahoo.co.in (R.Y.); \\ * Correspondence: rakesh_pu@yahoo.co.in (R.Y);
}

Received: 5.10.2021; Revised: 5.11.2021; Accepted: 8.11.2021; Published: 25.11.2021

\begin{abstract}
Xanthine and its derivatives belong to the class of purine alkaloids. They are natural bases holding nitrogen atoms within the molecular structure, and they have an effective pharmacological alteration in both animals and human beings. Substituted xanthine, theophylline/caffeine being prototype, is one of the derivatives which have shown prominent binding to adenosine receptors as agonist or antagonist. Various mechanistic approaches are involved in exerting bronchospasmolytic, neuroprotective, hypoglycemic, MAO modulatory, along cardiac effects. Mostly, xanthine derivatives reduce inflammation and bronchospasm in asthmatic conditions. Other therapeutics effects are in the management of cancer, Alzheimer's disease, vasoconstriction, and also possess excellent central nervous system-penetration ability; thus, they can also be used as stimulants and anti-depressants. Their actions are relatively very weak, but their pharmacological effects are also associated with snarl-up adenosine-mediated functions. An assortment of the biological profile of the xanthine scaffold attracted many research groups over the years to explore this nucleus vividly. The present review is aimed to cover every aspect of the xanthine moiety reported in the earlier years. This review covers all the major biological roles and various synthetic strategies adopted to synthesize xanthine moiety and its derivatives.
\end{abstract}

Keywords: xanthines; adenosine antagonists; Alzheimer's; MAO-inhibitors; 1,3-dimethyl uracil.

(C) 2021 by the authors. This article is an open-access article distributed under the terms and conditions of the Creative Commons Attribution (CC BY) license (https://creativecommons.org/licenses/by/4.0/).

\section{Introduction}

Various widely known biologically active scaffolds are available with a varying range of diversity in their biological profile. They may be organic or inorganic, either containing carbon atoms or one or more atoms other than carbon. The nitrogen-containing compounds are gaining more attention in the present era because of their wide diversity in their biological activities [1].

Xanthines are usually the derivative of purine alkaloids containing a nitrogen atom at positions 1-, 3-, 7- and 9, along with a carbonyl group at positions 2- and 6. Among naturally occurring xanthines, caffeine was the one that was isolated from coffee in the year 1820. The seeds of Theobroma cocoa contain caffeine and theobromine, while tea is obtained from the leaves of Thea sinensis containing caffeine which was isolated and named as "thein" further called theophylline, a dimethylxanthine [2].

Recent studies on caffeine (first isolated in 1819 by Ferdinand Runge) showed that it is also associated with Parkinson's disease as a treatment and preventive measure. This neuroprotective effect of caffeine is linked to its binding to adenosine A2A receptors [3-8]. 
Theophylline is chemically related as a natural metabolite of xanthine (I) which further metabolizes to uric acid (II) on oxidation by the enzyme xanthine oxidase at position-8 (Figure 1) [9].<smiles></smiles>

Xanthine<smiles>O=c1[nH]c(=O)c2[nH]c(=O)[nH]c2[nH]1</smiles>

Uric acid

Figure 1. Oxidation of xanthine to uric acid.

Thus, most research is based on synthesizing 8-substituted xanthine, and this scaffold is a key nucleus of many clinically available drugs. Pentoxifylline, a hemorheological agent, is a trisubstituted xanthine, while dimenhydrinate, an over-the-counter antiemetic, is 8chloroxanthine. Similarly, other substituted xanthines are found to act as nonselective inhibitors of adenosine receptors, selective inhibitors of phosphodiesterase, as antiinflammatory agents, and as monoamine oxidase-B (MAO-B) inhibitors in treating Parkinson's disease [10].

Xanthine and its derivative are less soluble than their parent compound purine because of the strong intramolecular bonds between $\mathrm{N}-\mathrm{H}$ groups and strong inter-base hydrogen bonds and base stacking. The increasing number of methyl groups at various positions on the xanthine nucleus profoundly affects its solubility [11-13]. The present review emphasizes the various synthetic strategies available to date to synthesize 8-substituted xanthines along with the many biological activities associated with this nucleus with regards to its structure-activity relationship studies and the effect of increasing alkyl chain at positions 1- and 3- and the effect of various substituents at position-8 [14].

\section{Materials and Methods}

\subsection{Synthetic Strategies.}

The various ways to synthesize various xanthine derivatives include synthesis of a key compound, 1-mono- or 1, 3-disubstituted-6-aminouracils. The starting compound possesses considerable diuretic activity, synthesized by Traübe using the classical method and further modified by Baum.

The proposed method includes condensation of substituted urea (1) with cyanoacetic acid (2) in the presence of acetic anhydride to result in intermediate cyanoacetyl urea (3). The resultant syrupy-based compound 3 on treatment with an alkali affects ring closure to form 6aminouracil (4) as depicted in Scheme 1.

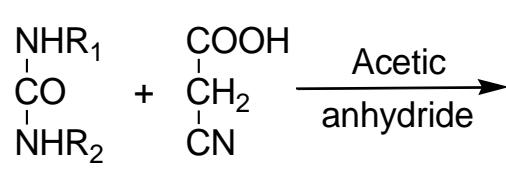

(1)
(2)

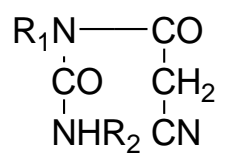

(3)

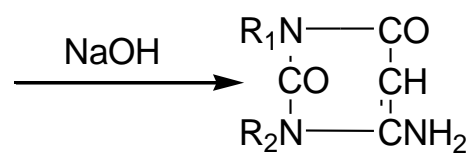

(4)

Scheme 1. Synthesis of 6-Aminouracil. 
In the case of mono-substituted urea $\left(\mathrm{R}^{\prime}=\mathrm{H}\right)$, the condensation occurs at unsubstituted nitrogen atom leading to the synthesis of 1-substituted-6-aminouracil, while in the case of disubstituted urea, condensation occurs at either nitrogen atom but predominantly at the nitrogen to which a smaller substituent group is attached [15].<smiles>[R7]n1c(N)cc(=O)n([R7])c1=O</smiles>

(4)<smiles>[R]Nc1c([N+](=O)[O-])c(=O)n([R])c(=O)n1[R]</smiles>

(5)<smiles>[R7]n1c(N)c(N)c(=O)n([R7])c1=O</smiles>

(6)

$\mathrm{R}_{1} / \mathrm{R}_{2}=\mathrm{CH}_{3} / \mathrm{C}_{3} \mathrm{H}_{7}$<smiles>[R3]C=Nc1c(N)n([R2])c(=O)n([R7])c1=O</smiles>

(6)

$+$

9

e<smiles>[R]C(=O)Nc1c(N)n([R2])c(=O)n([R])c1=O</smiles>

(10)
(8)

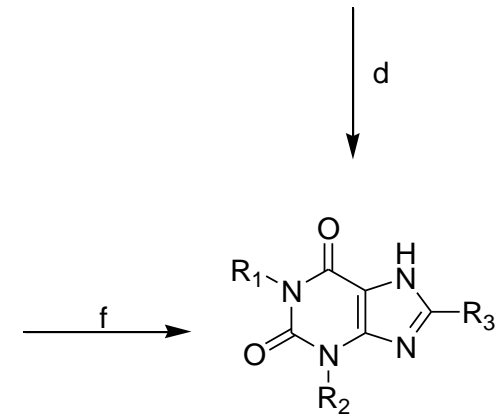

(11)

Scheme 2. (a) $\mathrm{NaNO}_{2}, \mathrm{CH}_{3} \mathrm{COOH}$; (b) $\mathrm{H}_{2}, 5 \% \mathrm{Pd} / \mathrm{C}, 50$ psi; (c) Various aldehydes, Ethanol, $\mathrm{CH}_{3} \mathrm{COOH}$; (d) diethyl azodicarboxylate, reflux; (e) acid chloride or carboxylic acid; (f) aqueous sodium hydroxide, reflux.

Various 1, 3, 8-trisubstituted xanthines were reported by Erickson et al. (Scheme 2), starting with the nitrosation of 1,3-dialkylsubstituted-6-aminouracil (4) to give 6-amino-1,3dialkyl-5-nitrosouracil (5) followed by catalytic hydrogenation to give 1,3-dialkyl-5,6diaminouracil (6). The diamino uracil, a key compound, obtained was then converted to 1, 3, 8 -trisubstituted xanthines by three different pathways that included condensation of diamino uracil with various aldehydes (7) to give imine (8) followed by oxidative cyclization with diethyl azodicarboxylate. Another method includes a reaction of 6 with carboxylic acid (9) to give amide (10) followed by cyclization with sodium hydroxide or direct melting of 6 and 9 to give amide (11) [16,17].

Another efficient one-pot method to synthesize xanthines was reported through direct coupling of carboxaldehyde with earlier available 5,6-diaminouracil (12) in the presence of mild conditions such as bromo dimethyl-sulfonium bromide (BDMS). In the presence of stoichiometric conditions, aldehydes on coupling with 12 gave high yields of xanthines (16) through an imine intermediate (14) or aminal form (15). The isolation of intermediates was unsuccessful except imine form, which was isolated at $10 \%$ buildup of bromo dimethylsulfonium bromide (BDMS) (Scheme 3) [18-23]. 
<smiles>CCn1c(N)c(N)c(=O)n(CC)c1=O</smiles>

(12)

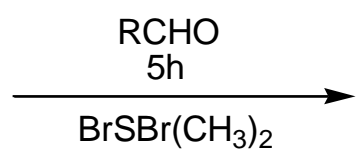<smiles>[R]c1nc2c([nH]1)c(=O)n(CC)c(=O)n2CC</smiles>

(16)<smiles>[Y]C(C)(O)Nc1c(N)n(CC)c(=O)n(CC)c1=O</smiles>

(13)<smiles>[R]/C=N/c1c(N)n(CC)c(=O)n(CC)c1=O</smiles>

(14)

Scheme 3. BDMS accelerated condensation in the synthesis of xanthine core.

Another approach includes the reaction of appropriate diamino uracil (17) and substituted benzaldehydes (18) to give a benzylidine adduct (19) which resulted in the formation of the imidazole ring of xanthine core on oxidative closure. The substituted aldehydes were the product of the alkylation reaction of $p$-hydroxybenzaldehyde with iodoacetate. The oxidative ring closure was affected by heating with ferric chloride to afford resultant xanthines (20) (Scheme 4) [1].<smiles>[R]n1c(N)c(N)c(=O)n(P)c1=O</smiles>

(17)

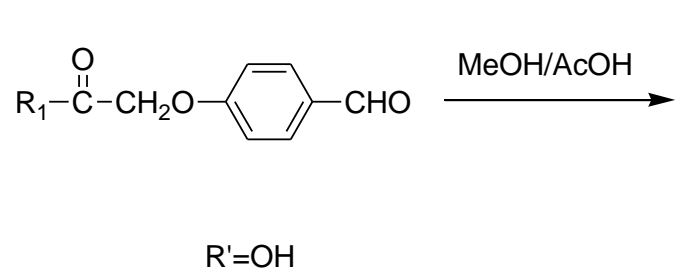

(18)<smiles>[R]C(=O)COc1ccc(/C=N/c2c(N)n([R])c(=O)n([R])c2=O)cc1</smiles>

(19)<smiles>[R]C(=O)COc1ccc(-c2nc3c(=O)n([R])c(=O)n([R])c3[nH]2)cc1</smiles>

(20)

Scheme 4. Synthetic approach to functionalized xanthine derivatives.

The presence of solvent has a considerable effect at this step. In the presence of ethanol, considerable ethyl ester (21) will be formed, while in dimethylformamide (DMF), the carboxylic acid congener of xanthine (22) will be formed. The coupling of this acid congener with various amines presents a solubility problem, so $N$-hydroxysuccinimide ester (23) of 22 was prepared, which proved as an active form of the drug to be coupled with various amines 
in the presence of Dimethylformamide (DMF) to form amide derivatives of xanthine (24), while the ethyl ester (21) can also be aminolyzed directly to give amides (Scheme 5) [1].

(19)

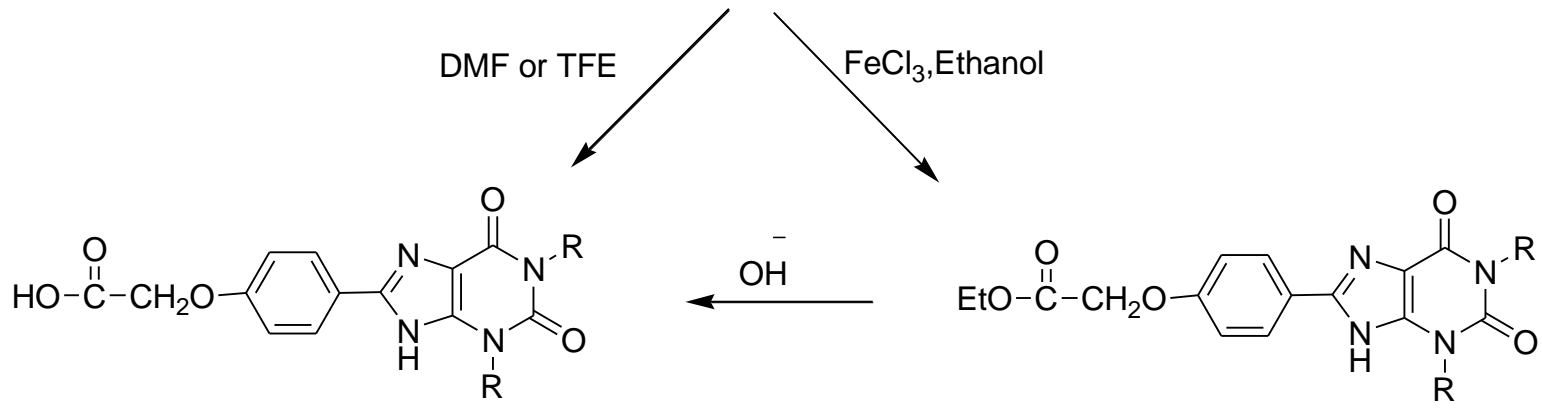

(22)

(21)

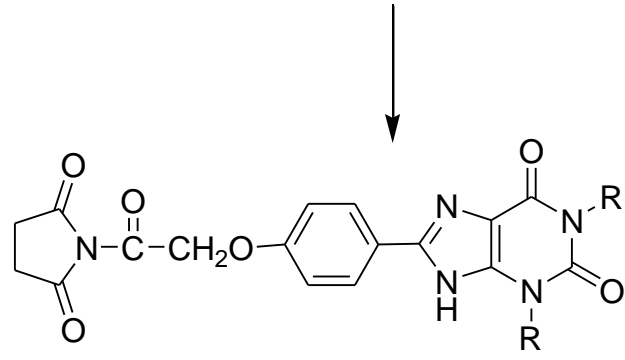

(23)

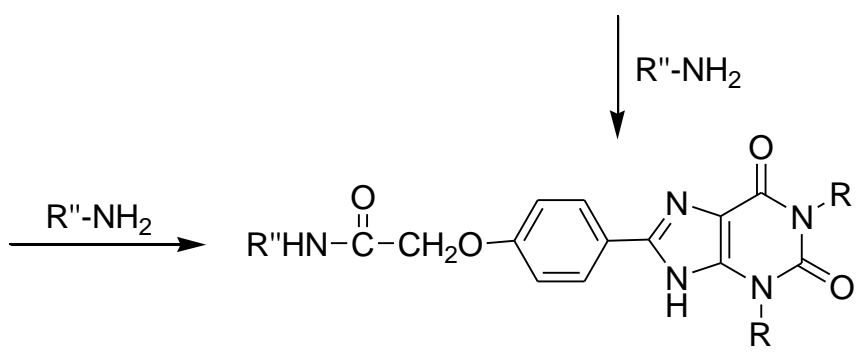

(24)

Scheme 5. Method of coupling and chain elongation of xanthines.

Another coupling reaction between sulfophenylxanthines and amines resulted in sulfonamide derivatives of xanthines. The general 1, 3-dialkyl-8-phenylxanthines exhibit low solubility in water; thus, the introduction of the sulfonate group was done to increase the solubility followed by the synthesis of a series of sulfonamide derivatives.<smiles>CCCn1c(=O)[nH]c2nc(-c3ccc(S(=O)(=O)O)cc3)[nH]c2c1=O</smiles>

(25)

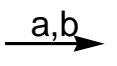

(26)

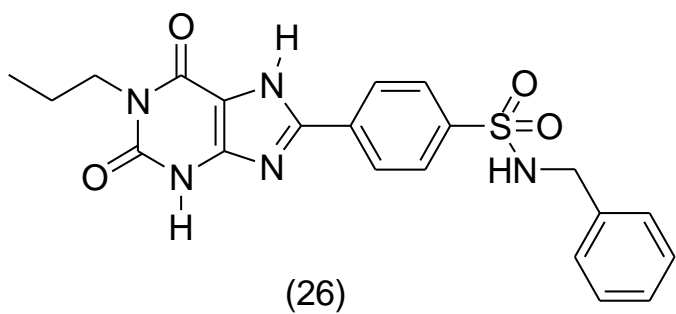

Scheme 6. (a) Chlorosulfonic acid, r.t., overnight; (b) benzylamine, anhydrous pyridine/ DMF, r.t., 3 days, reflux, 3 hrs.

The sulfonic acid (25) was first converted to its chloro sulfonyl derivative with thionyl chloride, chlorosulfonic acid, phosphorous oxychloride, or phosphorous pentachloride, followed by its treatment with an appropriate amine to give sulfonamide (26) but with poor yield (Scheme 6) [24].

Thus, the same method was used to determine whether nitro phenoxides are betterleaving groups than halogenides. The nitrophenoxysulfonyl benzene derivative of xanthine [25] which can be synthesized easily, crystalline, highly lipophilic, and stable, treated with various amines in dimethyl sulfoxide (DMSO) at room temperature for $30 \mathrm{~min}$., along with heating at $150{ }^{\circ} \mathrm{C}$ for $3 \mathrm{hrs}$ to obtain a good yield of sulfonamides 26-37 (Scheme 7). 
<smiles>[R]n1c(=O)c2[nH]c(-c3ccc(S(=O)(=O)Oc4ccc([N+](=O)[O-])cc4)cc3)nc2n([R2])c1=O</smiles><smiles>[R]N([R3])S(=O)(=O)c1ccc(-c2nc3[nH]c(=O)n(CCC)c(=O)c3[nH]2)cc1</smiles>

(26-37)

Scheme 7. (c) primary or secondary amine, method $\mathrm{A}=\mathrm{DMSO}, 150{ }^{\circ} \mathrm{C}, 3 \mathrm{~h}$; method $\mathrm{B}=\mathrm{DMSO}, 150{ }^{\circ} \mathrm{C}, 5 \mathrm{~h}$; method $\mathrm{C}=\mathrm{DMSO}$, r.t., 72h, argon; method $\mathrm{D}=\mathrm{DMF}$, r.t., 48h, reflux, $1 \mathrm{~h}$.

Depending upon the substituent attached to the xanthine nucleus, different methods were applied to obtain sulfonamide derivatives in high yields, followed by their purification by column chromatography as given in Table 1 [26].

Table 1. Substituents and yields of synthesized xanthin-8-yl-benzenesulfonamide derivatives.

\begin{tabular}{c|c|c|c|c|c} 
Compound No. & $\mathbf{R}_{\mathbf{1}}$ & $\mathbf{R}_{\mathbf{2}}$ & $\mathbf{R}_{\mathbf{3}}$ & $\mathbf{R}_{\mathbf{4}}$ & \% Yield \\
\hline 26 & $\mathrm{Pr}$ & $\mathrm{H}$ & $\mathrm{Bn}$ & $\mathrm{H}$ & 51 \\
\hline 27 & $\mathrm{Pr}$ & $\mathrm{H}$ & $-\mathrm{CH}_{2} \mathrm{CH}_{2} \mathrm{Ph}$ & $\mathrm{H}$ & 88 \\
\hline 28 & $\mathrm{Pr}$ & $\mathrm{H}$ & $-\mathrm{CH}_{2} \mathrm{CH}_{2} \mathrm{OH}$ & $\mathrm{H}$ & 28 \\
\hline 29 & $\mathrm{Pr}$ & $\mathrm{H}$ & $-\mathrm{CH}_{2} \mathrm{COOH}$ & $\mathrm{H}$ & 34 \\
\hline 30 & $\mathrm{Pr}$ & $\mathrm{H}$ & $\mathrm{Pr}$ & $\mathrm{H}$ & 33 \\
\hline 31 & $\mathrm{Pr}$ & $\mathrm{H}$ & $\mathrm{Ph}$ & $\mathrm{H}$ & 50 \\
\hline 32 & $\mathrm{Pr}$ & $\mathrm{H}$ & $-\mathrm{CH}_{2}-\mathrm{CH}_{2}-\mathrm{N}(\mathrm{Bn}) \mathrm{CH}_{2}-\mathrm{CH}_{2-}$ & $\mathrm{H}$ & 61 \\
\hline 33 & $\mathrm{Me}$ & $\mathrm{Me}$ & $\mathrm{Pr}$ & $\mathrm{H}$ & 42 \\
\hline 34 & $\mathrm{Me}$ & $\mathrm{Me}$ & $-\mathrm{CH}_{2} \mathrm{CH}_{2} \mathrm{Ph}$ & $\mathrm{H}$ & 44 \\
\hline 35 & $\mathrm{Me}$ & $\mathrm{Me}$ & $\mathrm{Bu}$ & $\mathrm{H}$ & 51 \\
\hline 36 & $\mathrm{Me}$ & $\mathrm{Me}$ & $-\mathrm{CH}_{2} \mathrm{CH}_{2} \mathrm{OH}$ & $\mathrm{H}$ & 28 \\
\hline 37 & $\mathrm{Me}$ & $\mathrm{Me}$ & $-\mathrm{CH}_{2} \mathrm{COOH}$ & & $0 \mathrm{CH}$
\end{tabular}<smiles>[R]CCOc1ccc(C=O)cc1OC</smiles>

(38)<smiles>[R]CCOc1ccc(C=Nc2c(N)n(C)c(=O)n(C)c2=O)cc1OC</smiles><smiles>[R]CCOc1ccc(-c2nc3c([nH]2)c(=O)n(C)c(=O)n3C)cc1OC</smiles>

$41(a-e)$

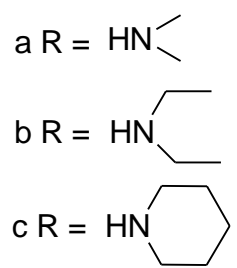

Scheme 8. Synthetic route to compounds 41 (a-e) Reagents and conditions (a) $\mathrm{MeOH} / \mathrm{CH}_{3} \mathrm{COOH}$, r.t., 18h; (b) $\mathrm{SOCl}_{2}$, reflux, 30-40 min., $\mathrm{NH}_{4} \mathrm{OH}$.

A series of 8-(substituted-phenyl)-xanthines were synthesized by the reaction of 5,6diamino-1,3-dimethyluracil (38) with various substituted aldehydes 39a-e, 42a-e, 45a-e to give https://biointerfaceresearch.com/ 
corresponding Schiff bases/benzylidene derivatives 40a-e, 43a-e, 46a-ein methanol: glacial acetic acid $(\mathrm{MeOH}-\mathrm{AcOH})(4: 1)$ at room temperature for 18 hours. The cyclization of these benzylidene derivatives in refluxing thionyl chloride for about 1 hour yielded the resultant xanthine derivatives 41a-e, 44a-e, and 47a-e.

The aldehydes 39a-e, 42a-e, 45a-e prepared by reaction of vanillin, isovanillin, and 3hydroxybenzaldehyde with the hydrochlorides of dialkylaminoethyl chloride such as $\beta$ dimethylaminoethylchloride, $\beta$-diethylaminoethylchloride, 1-(2-chloroethyl)-piperidine, 4-(2chloroethyl)-morpholine, and 1-(2-chloroethyl)-pyrrolidine in the presence of potassium carbonate (anhydrous) in refluxing ethyl methyl ketone (Scheme 8-10) [27].

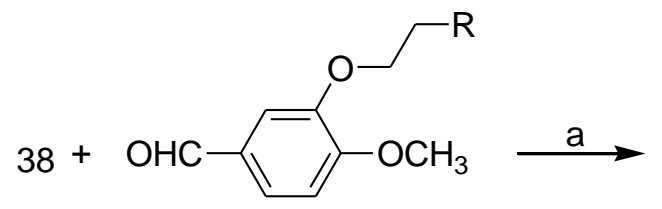

$42(a-e)$<smiles>[R]CCOc1cc(C=Nc2c(N)n(C)c(=O)n(C)c2=O)ccc1OC</smiles><smiles>[2H]CCOc1cc(-c2nc3c([nH]2)c(=O)n(C)c(=O)n3C)ccc1OC</smiles>

44(a-e)

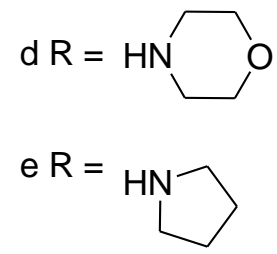

Scheme 9. Synthetic route to compounds 44 (a-e). Reagents and conditions (a) $\mathrm{MeOH} / \mathrm{CH}_{3} \mathrm{COOH}$, r.t., 18h; (b) $\mathrm{SOCl}_{2}$, reflux, 30-40 min., $\mathrm{NH}_{4} \mathrm{OH}$.

On changing positions of alkyl aminoalkoxy side chain and - $\mathrm{OCH}_{3}$ group arrangement on the 8-phenyl ring, there is a significant change in the properties of various xanthine derivatives towards adenosine receptor subtypes binding, and this change depends on the type of substituents attached. The mono-substituted xanthine derivatives 47 (a-e), containing only one polar side chain at position-3 of the 8-phenyl group, displayed a potent affinity for $\mathrm{A}_{1}$ and $\mathrm{A}_{2 \mathrm{~A}}$ receptor subtypes adenosine. The presence of a $-\mathrm{OCH}_{3}$ substituent ortho to a polar side chain at 3- or 4-position of phenyl ring resulted in increased selectivity for $\mathrm{A}_{2}$ over $\mathrm{A}_{1}$ receptors. A polar side chain at 3-position of the 8-phenyl ring without a - $\mathrm{OCH}_{3}$ group resulted in almost equal selectivity for both subtypes. It can be established that appropriate selection and placement of aryl substituents may lead to the synthesis of potent and selective xanthine-based adenosine receptor antagonists. 
38<smiles>[R]CCOc1cccc(C=O)c1</smiles>

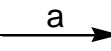<smiles>[R]CCOc1cccc(C=Nc2c(N)n(C)c(=O)n(C)c2=O)c1</smiles>

$45(\mathrm{a}-\mathrm{e})$

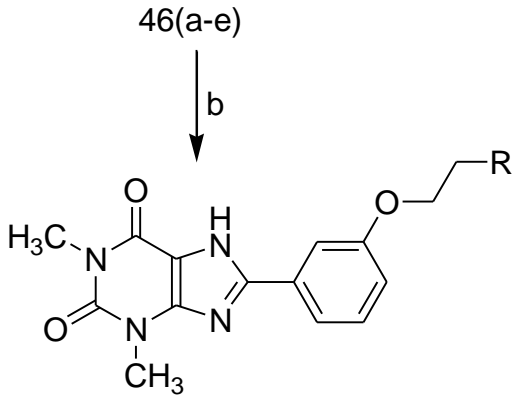

$47(\mathrm{a}-\mathrm{e})$
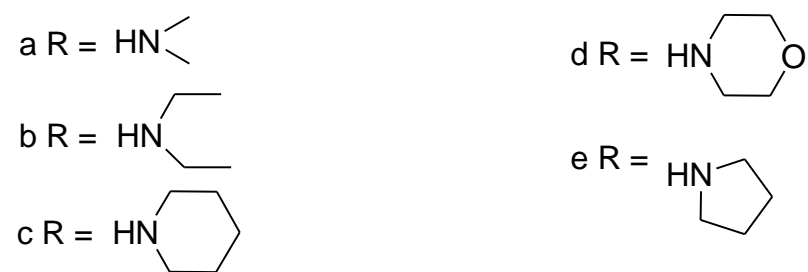

Scheme 10. Synthetic route to compounds 47 (a-e). Reagents and conditions (a) $\mathrm{MeOH} / \mathrm{CH}_{3} \mathrm{COOH}$, r.t., 18h; (b) $\mathrm{SOCl}_{2}$, reflux, 30-40 min., $\mathrm{NH}_{4} \mathrm{OH}$.

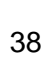<smiles></smiles><smiles></smiles>

$48(a-g)$<smiles>CCOc1ccc(C=Nc2c(N)n(C)c(=O)n(C)c2=O)cc1</smiles>

$49(a-g)$<smiles>Cn1c(=O)c2[nH]c(-c3ccc(O)cc3)nc2n(C)c1=O</smiles>

$50(a-g)$

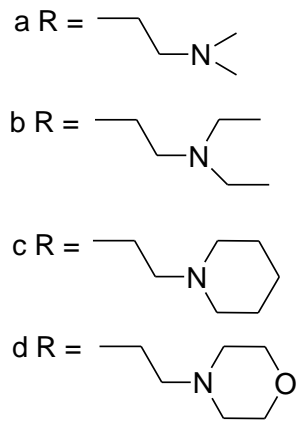

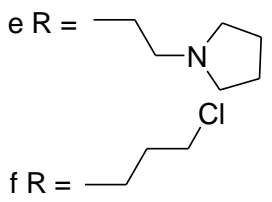

$g R=-O-\square$

Scheme 11. Synthetic route to 8-(p-substitutedphenyl)-xanthine derivatives. Reagents and conditions (a) $\mathrm{MeOH} / \mathrm{CH}_{3} \mathrm{COOH}$, r.t., $18 \mathrm{~h}$; (b) $\mathrm{SOCl}_{2}$, reflux. 
In continuation to above, the impact of substituting polar dialkylaminoethoxy substituent at the para position of the 8-phenyl ring of xanthine on adenosine receptor binding affinity and selectivity was studied. Also, the introduction of a methylene spacer between the aromatic unit and the $\mathrm{C} 8$ of the xanthine nucleus was studied to determine its effect on biological activity. The 5, 6-diamino-1, 3-dimethyluracil (38) was treated with substituted aldehydes $48 \mathrm{a}-\mathrm{g}$ to afford benzylidene adducts $49 \mathrm{a}-\mathrm{g}$ in the presence of methanol and $\mathrm{MeOH} / \mathrm{AcOH}(4: 1)$ at room temperature for 18 hours. These adducts were refluxed in thionyl chloride for 1 hour to afford oxidative cyclization, resulting in the formation of targeted xanthines (50a-g) (Scheme 11) [28,29].

The imidazole-derived xanthines were also reported to possess adenosine binding affinity and antihistaminic properties too. The effect was studied by thermally fusing chloroalkoxy derivative of xanthine, 50f with powdered imidazole to afford corresponding congener 51 (Scheme 12), which was the potent compound for $\mathrm{A}_{2 \mathrm{~A}}$ adenosine receptor [30,31].

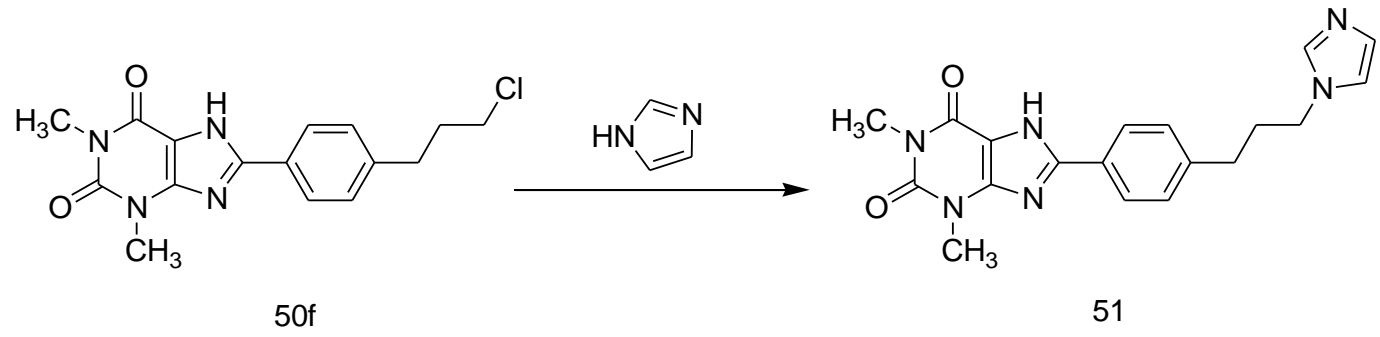

Scheme 12. Synthesis of imidazole-derived xanthines.

Yan et al. reported a process for the synthesis of a sulfonic acid-nitrophenyl ester of xanthines starting from the chlorination of potassium salt of $p$-sulfobenzoic acid (52) at low temperature with the help of chlorosulfonic acid to give sulfonyl chloride (53), which was further converted to either meta-(54) or para-(nitrophenoxysulfonyl)-benzoic acid (55) under Schotten-Baumann conditions [32].

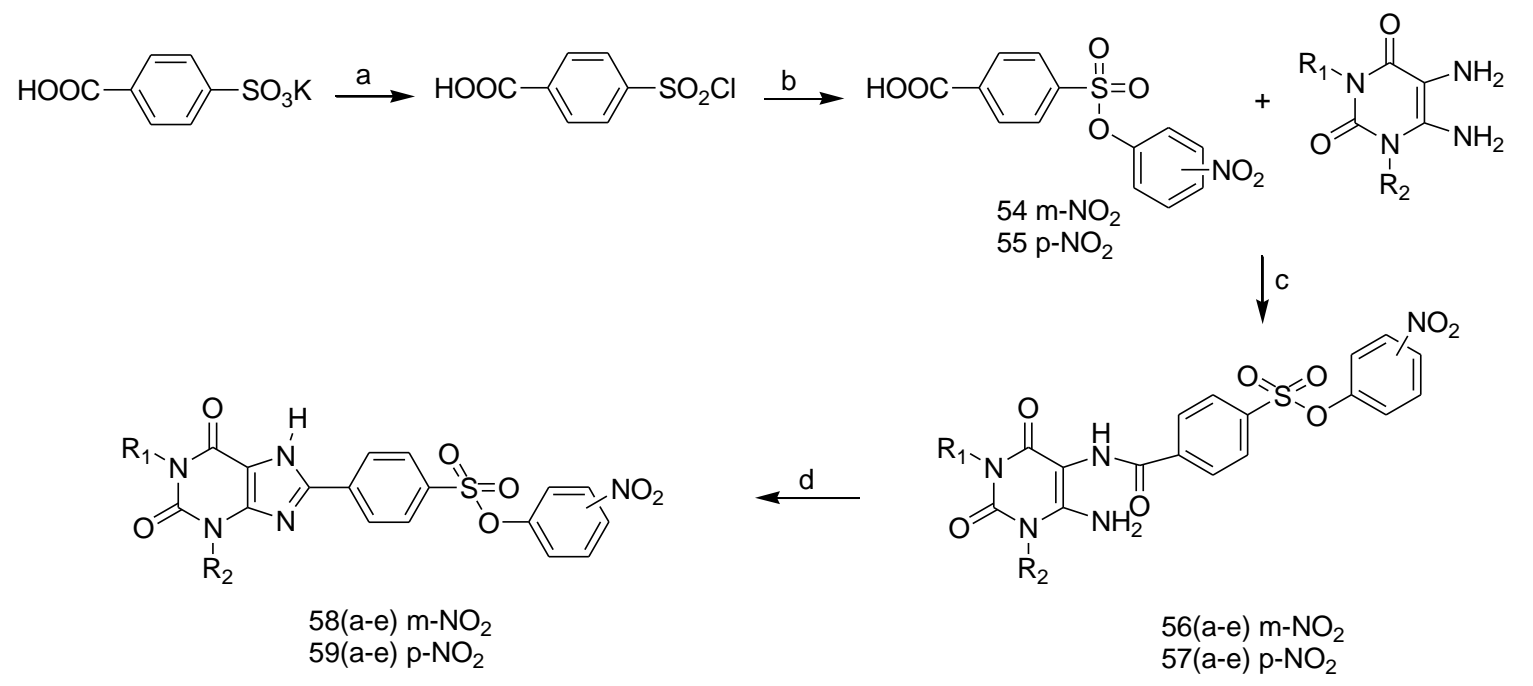

Scheme 13. Synthesis of nitro phenyl ester prodrugs of $p$-sulfophenyl xanthine derivatives. Reagents and conditions. (a) chlorosulfonic acid, r.t., overnight, ice; (b) $m$-nitrophenol or $p$-nit rophenol, THF, pH=8-9, 4h; (c) $\mathrm{EDC}, \mathrm{MeOH}$, rt; (d) PPSE, $120^{\circ} \mathrm{C}, 10 \mathrm{~min} ., 170{ }^{\circ} \mathrm{C}, 2 \mathrm{hr}$.

The condensation of 54 and 55 with 5,6-diaminouracil using EDC as a condensing agent resulted in 6-amino-5-\{4-[( $m$-nitrophenoxy $)$-sulfonyl $]$-benzamido $\}$-uracil derivatives 56a-e and 6-amino-5-\{4-[( $p$-nitrophenoxy)-sulfonyl]-benzamido $\}$-uracil derivatives 57a-e. The heating of these compounds with polyphosphoric acid trimethylsilyl ester (PPSE) at $170^{\circ} \mathrm{C}$ 
for 2 hours resulted in the synthesis of the corresponding meta- 58a-e and paranitrophenylsulfonyl phenyl xanthine derivatives 59a-e (Scheme 13, Table 2) [25,32-36].

Table 2. Various substituents on nitrophenyl ester prodrugs of $p$-sulfophenyl xanthine derivatives.

\begin{tabular}{c|c|c|c} 
Compound No. & $\mathbf{R}_{\mathbf{1}}$ & $\mathbf{R}_{\mathbf{2}}$ & Nitro \\
\hline $58 \mathrm{a}$ & Methyl & Methyl & $m-$ \\
\hline $58 \mathrm{~b}$ & Propyl & Propyl & $m-$ \\
\hline $58 \mathrm{c}$ & Methyl & H & $m-$ \\
\hline $58 \mathrm{~d}$ & Propyl & H & $m-$ \\
\hline $58 \mathrm{e}$ & Butyl & H & $m-$ \\
\hline $59 \mathrm{a}$ & Methyl & Methyl & $p-$ \\
\hline $59 \mathrm{~b}$ & Propyl & Propyl & $p-$ \\
\hline $59 \mathrm{c}$ & Methyl & H & $p-$ \\
\hline $59 \mathrm{~d}$ & Propyl & H & $p-$ \\
\hline $59 \mathrm{e}$ & Butyl & H & $p-$
\end{tabular}

Furthermore, a series of 8-heterocycle-substituted xanthines has been described. The several heterocycles introduced were pyrazole, isoxazole, pyridine, and pyridazine at 8position of the xanthine nucleus, and different spacers such as substituted acetamide, oxyacetamide, and urea moieties were introduced. Various different groups were also introduced at 3- or 4- positions of the phenylacetamide moiety.

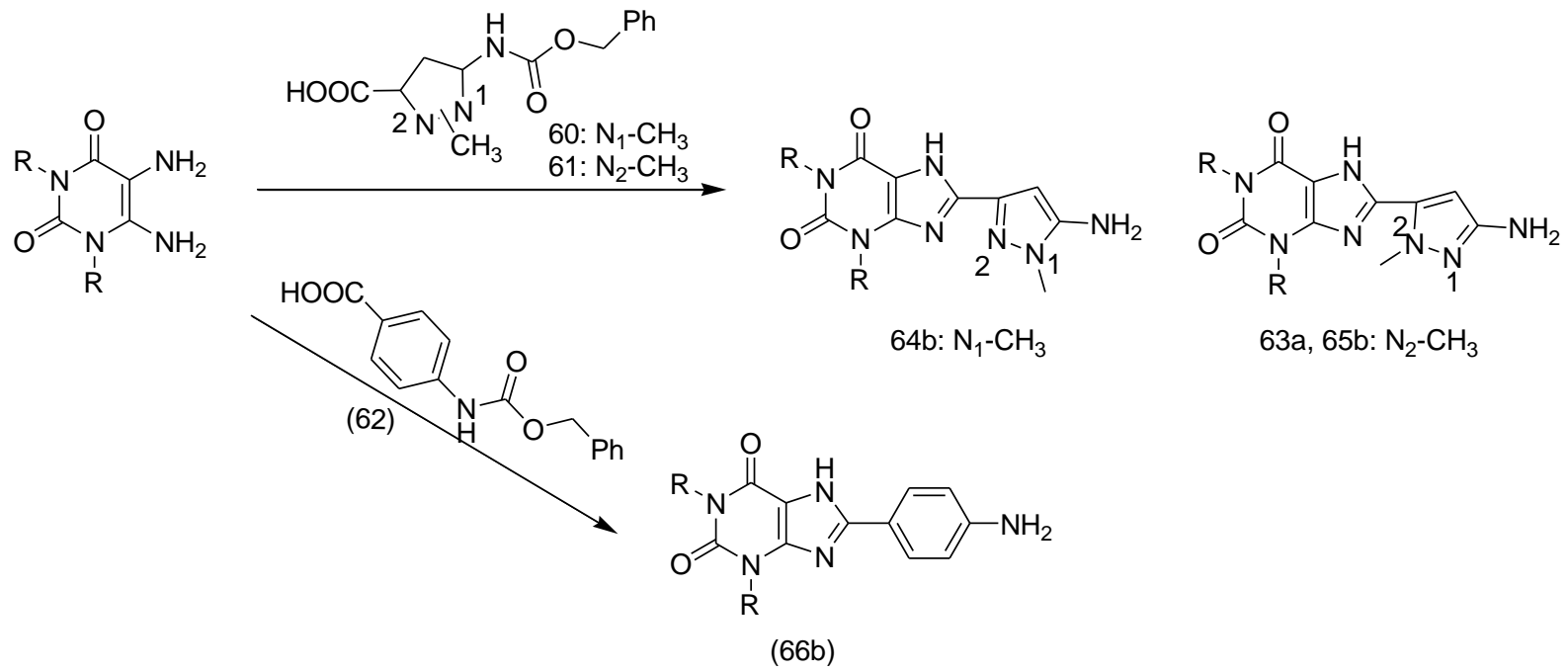

Scheme 14. Reagents: (1) Methanol, EDCI, 4-5 h; (2) Methanol, NaOH, 2.5 N, $70{ }^{\circ} \mathrm{C}, 12 \mathrm{~h}$.

The reaction of 1, 3-disubstitued-5, 6-diaminouracil with pyrazole carboxylic acid (60, 61) and phenyl carboxylic acid (62) in methanol using 1-ethyl-3-(3-dimethylaminopropyl)carbodiimide (EDCI) as a condensing agent then ring closure at $70{ }^{\circ} \mathrm{C}$ in the presence of sodium hydroxide yielded 8-aminopyrazolo- and 8-aminophenylxanthines 63a, 64b, 65b and 66b (Scheme 14) [37] [16,37].

Furthermore, 9-deazaxanthine (9-dAXs) (1,3-dialkyl-8-substituted-1H-pyrrolo [3,2- $d]$ pyrimidine- 2,4-(3H, 5H)-diones) derivatives were synthesized by the reaction of 1,3-dialkyl6-methyl-5-nitropyrimidine-2,4-(1H,3H)-dione (67) with appropriate benzaldehydes (68) and piperidine in dry dioxane under argon atmosphere and refluxed for 5-70 h to give nitrostyryl derivatives (69). These 6-styryluracils were cyclized to their corresponding 9-dAXs (70) and to their equivalent 9-halogen derivatives (71) containing an oxyacetic acid or ester group on the para position of the 8-phenyl ring (Scheme 15) [38-41]. 
<smiles>[R3]n1c(C)c([N+](=O)[O-])c(=O)n([R3])c1=O</smiles>

(67)<smiles>[Z][Y]([H])([H])N=O</smiles>

(68)
$\mathrm{W}=\mathrm{O}, \mathrm{N}(\mathrm{CHO})$<smiles>[Y]c1ccc(/C=C/c2c([N+](=O)[O-])c(=O)n([R7])c(=O)n2[R3])cc1</smiles>

(69) b or c

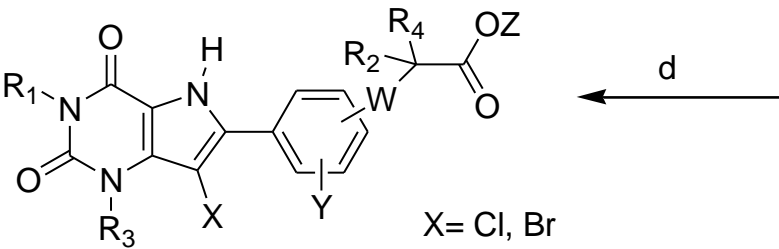

(71)<smiles>[Y]c1ccc(-c2cc3c([nH]2)c(=O)n([R7])c(=O)n3[R3])cc1</smiles>

(70)

Scheme 15. Reagents (a) Dioxane/piperidine/reflux; (b) $\mathrm{P}(\mathrm{OEt})_{3}$, reflux; (c) $\mathrm{Na}_{2} \mathrm{~S}_{2} \mathrm{O}_{4} / \mathrm{HCOOH}$, reflux; (d) $\mathrm{SO}_{2} \mathrm{Cl}_{2}$ or $\mathrm{Br}_{2} / \mathrm{AcOH}$.

Balo et al. reported the synthesis of novel 1- and 8-substituted-3-furfuryl xanthines as described in Scheme 16. The condensation of 1-furfuryl urea with cyanoacetic acid [42] gave uracil (72), which was further alkylated directly by using $15 \%$ aqueous sodium hydroxide $(\mathrm{NaOH})$ or with appropriate alkyl halide [43] or by refluxing with ammonium sulfate in hexamethyldisilazane (HMDS) and then the addition of iodine and appropriate halide $[44,45]$ to give 1,3-disubstituted-6-aminouracil (73). The nitrosation of 73a-1 with sodium acetate in acetic acid followed by reduction with sodium dithionite gave diaminouracils 75a-1. The condensation of these diaminouracils with a different carboxylic acid in the presence of diisopropylcarbodiimide (DIC) in methanol and then cyclization with $2.5 \mathrm{~N} \mathrm{NaOH}$ in methanol under reflux afforded targeted xanthines 76 (a-aa) Table 3 [46].

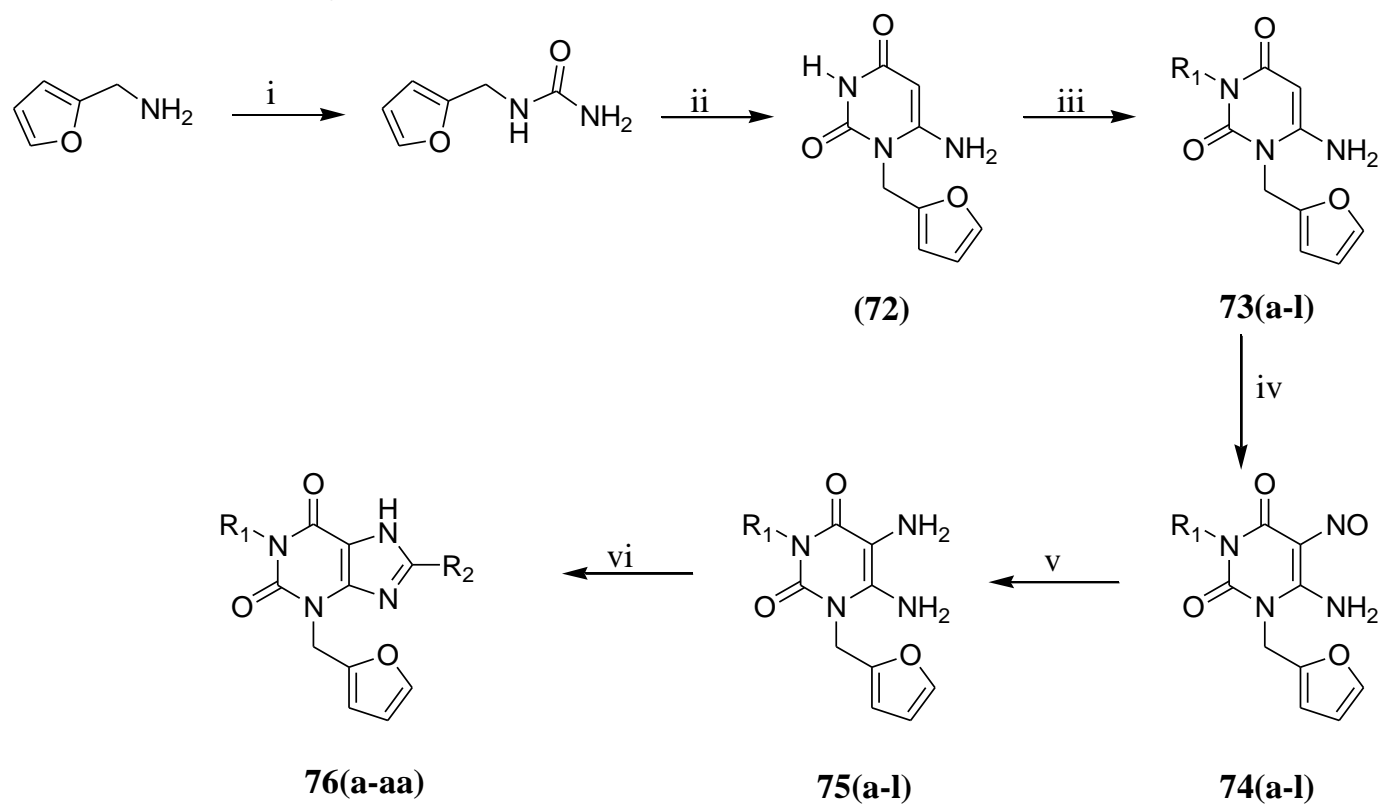

Scheme 16. Reagents and conditions: (i) $\mathrm{KOCN}, \mathrm{H}_{2} \mathrm{SO}_{4}$; (ii) $\mathrm{NCCH}_{2} \mathrm{COOH}$; (iii) (a) $\mathrm{RX}, \mathrm{NaOH}$, EtOH; (b) $\left(\mathrm{NH}_{4}\right)_{2} \mathrm{SO}_{4}, \mathrm{HMDS}, \mathrm{I}_{2}, \mathrm{RX}, \mathrm{Na}_{2} \mathrm{~S}_{2} \mathrm{O}_{3}, \mathrm{H}_{2} \mathrm{O}$; (iv) $\mathrm{NaNO}_{2}, \mathrm{AcOH}$; (v) $\mathrm{Na}_{2} \mathrm{~S}_{2} \mathrm{O}_{4}, \mathrm{NH}_{4} \mathrm{OH}$; (vi) (a) $\mathrm{R}_{2} \mathrm{COOH}, \mathrm{DIC}$, $\mathrm{MeOH}, \mathrm{rt}, 0.5 \mathrm{~h}$; (b) $2.5 \mathrm{~N} \mathrm{NaOH}, \mathrm{MeOH}$, reflux, 10min. $-1 \mathrm{~h}$. 
Table 3. Various substituents of 1- and 8-substituted-3-furfuryl xanthines 76(a-aa).

\begin{tabular}{|c|c|c|c|}
\hline S. No. & Compound & $\mathbf{R}_{1}$ & $\mathbf{R}_{2}$ \\
\hline 1 & $76 \mathrm{a}$ & Methyl & Furan-2-yl \\
\hline 2 & $76 \mathrm{~b}$ & Ethyl & Phenyl \\
\hline 3 & $76 c$ & Ethyl & Furan-2-yl \\
\hline 4 & $76 \mathrm{~d}$ & Ethyl & Thiphen-2-yl \\
\hline 5 & $76 \mathrm{e}$ & Propyl & Phenyl \\
\hline 6 & $76 f$ & Propyl & Furan-2-yl \\
\hline 7 & $76 \mathrm{~g}$ & Propyl & Thiphen-2-yl \\
\hline 8 & $76 \mathrm{~h}$ & Isobutyl & Phenyl \\
\hline 9 & $76 \mathrm{i}$ & Isobutyl & Thiphen-2-yl \\
\hline 10 & $76 \mathrm{j}$ & Pentyl & Phenyl \\
\hline 11 & $76 \mathrm{k}$ & Pentyl & Thiphen-2-yl \\
\hline 12 & 761 & Cyclopropylmethyl & Thiphen-2-yl \\
\hline 13 & $76 \mathrm{~m}$ & Cyclopropylmethyl & 2,6-Difluorophenyl \\
\hline 14 & $76 n$ & Prop-2-ynyl & Thiophen-2-yl \\
\hline 15 & 760 & Prop-2-ynyl & 2,6-Difluorophenyl \\
\hline 16 & $76 p$ & Allyl & Thiophen-2-yl \\
\hline 17 & $76 q$ & Allyl & 2,6-Difluorophenyl \\
\hline 18 & $76 r$ & 2-Methoxyethyl & Phenyl \\
\hline 19 & $76 \mathrm{~s}$ & 2-Methoxyethyl & Thiophen-2-yl \\
\hline 20 & $76 \mathrm{t}$ & 2-Methoxyethyl & 2,6-Difluorophenyl \\
\hline 21 & $76 u$ & 2-Ethoxyethyl & Phenyl \\
\hline 22 & $76 \mathrm{v}$ & 2-Ethoxyethyl & Thiophen-2-yl \\
\hline 23 & $76 w$ & 2-(Methylthio)ethyl & Thiophen-2-yl \\
\hline 24 & $76 x$ & 2-(Methylthio)ethyl & 2,6-Difluorophenyl \\
\hline 25 & $76 y$ & 2-(Ethylthio)ethyl & Phenyl \\
\hline 26 & $76 z$ & 2-(Ethylthio)ethyl & Furan-2-yl \\
\hline 27 & 76aa & 2-(Ethylthio)ethyl & Thiophen-2-yl \\
\hline
\end{tabular}

Another efficient method for synthesizing 8-substituted xanthines includes the reaction of 5, 6-diaminouracils, and carboxaldehyde using bromo dimethylsulfonium bromide (BDMS) $[18,47]$. The coupling of diamino uracil to methyl-2-formylbenzoate under BDMS gave xanthine benzoate (77) after filtration. The methylation of xanthine and saponification of benzoate yielded methylxanthine benzoic acid (79) (Scheme 17) [48].<smiles>CCn1c(N)c(N)c(=O)n(CC)c1=O</smiles><smiles>COC(=O)c1ccccc1C=O</smiles><smiles>CCn1c(=O)c2c(nc(-c3ccccc3C(=O)O)n2C)n(CC)c1=O</smiles>

(79)<smiles>CCn1c(=O)c2[nH]c(-c3ccccc3C(=O)OC)nc2n(CC)c1=O</smiles>

$\mathrm{CH}_{3} \mathrm{I}, \mathrm{K}_{2} \mathrm{CO}_{3}$ DMF<smiles>CCn1c(=O)c2c(nc(-c3ccccc3C(=O)OC)n2C)n(CC)c1=O</smiles>

(78)

Scheme 17. Synthesis of 8-substituted xanthines.

Another method for synthesizing xanthines is synthesizing 1-substituted uracil derivatives 80a-b, according to Papesch and Schröder [49]. From 80a-b, xanthines were obtained by different pathways. One method was their conversion to nitroso uracils $81 \mathrm{a}-\mathrm{b}$. The reaction of $81 \mathrm{~b}$ with a mixture of benzylamine hydrochloride at high temperature yielded the xanthine derivative $83 \mathrm{~d}$. Another method includes the reduction of nitrosouracils to 
diaminouracils $82 \mathrm{a}-\mathrm{b}$ by sodium dithionite. Being unstable due to oxidative dimerization in the presence of oxygen, they were used further without any purification [50]. The diaminouracil $82 \mathrm{a}$ was reacted with triethyl orthoformate to yield another xanthine derivative $83 \mathrm{~b}$ (Scheme 18) $[51]$.

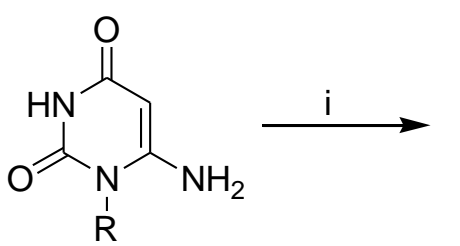<smiles>CC#CC</smiles><smiles>CPn1c(N)c(N)c(=O)[nH]c1=O</smiles>

80a R=benzyl

$80 \mathrm{~b} R=$ methyl

81a R=benzyl

$81 \mathrm{~b} R=$ methyl

82a R=benzyl $82 \mathrm{~b} \mathrm{R}=$ methyl
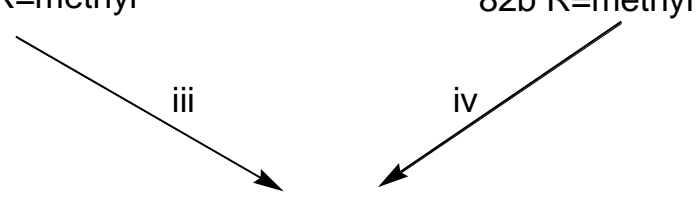<smiles>[R7]c1nc2c(c(=O)[nH]c(=O)n2P)n1P</smiles>

$83 b, 83 d$

Scheme 18. Reagents (i) $\mathrm{NaNO}_{2}, \mathrm{H}_{2} \mathrm{O} / \mathrm{CH}_{3} \mathrm{COOH}$, (ii) $\mathrm{Na}_{2} \mathrm{~S}_{2} \mathrm{O}_{4}, \mathrm{H}_{2} \mathrm{O} / \mathrm{NH}_{3}$, (iii) $\mathrm{C}_{6} \mathrm{H}_{5} \mathrm{CH}_{2} \mathrm{NH}_{2} \cdot \mathrm{HCl}$, $\mathrm{C}_{6} \mathrm{H}_{5} \mathrm{CH}_{2} \mathrm{NH}_{2}$, 3h, $170{ }^{\circ} \mathrm{C}$; (iv) $\left(\mathrm{C}_{2} \mathrm{H}_{5} \mathrm{O}\right)_{3} \mathrm{CH}, 12 \mathrm{~h}$, heat.

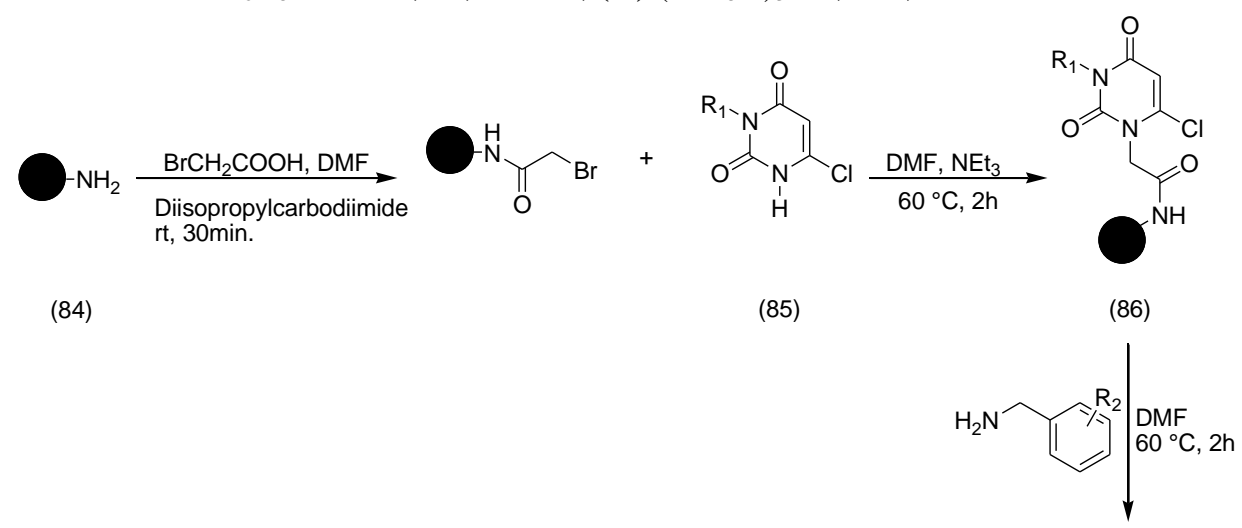

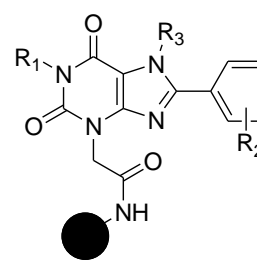

(89) 95\% TFA rt, $2 \times 15 \mathrm{~min}$.<smiles></smiles>

(90)

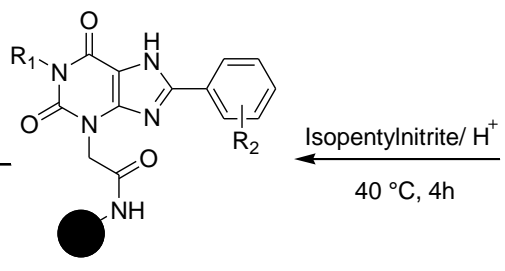

(88)

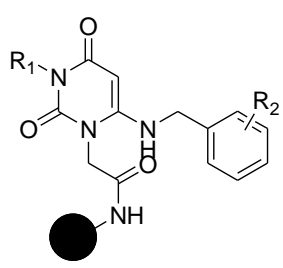

(87)

Scheme 19. Solid-phase synthesis of fully substituted xanthine. 
A solid-phase technology was also employed to synthesize fully substituted xanthine derivatives. The reaction included coupling bromoacetic acid to the free amino function of the solid support (84). Through the nitrogen atom, 1-alkyl-4-chlorouracil (85) was attached to the solid phase by the method of alkylation to form an intermediate 86 . The chlorine atom of resinbound uracil intermediate was replaced by $1^{\circ}$ benzylamines to give 4-benzylaminouracil (87). The solid support bound 87 was treated with isopentyl nitrite in acetic acid to form a nitroso compound that undergoes immediate ring closure to form a xanthine derivative (88). The progress at each step was monitored by the cleavage of the reaction product from the solid phase and its analysis by UV spectroscopy. The alkylation of 88 in the presence of excess alkylating agent and triethylamine gave fully substituted xanthine 89 . The solid support was finally cleaved by the action of trifluoroacetic acid resulting in final fully substituted xanthines (90). The cleavage procedure included treating resin twice with $95 \%$ trifluoroacetic acid and washing with 95\% trifluoroacetic acid, dichloromethane, and trifluoroethanol. The combined solvents were removed over $\mathrm{KOH}$ in an evacuated desiccator. Residues were lyophilized twice from dilute acetic acid and purified directly by HPLC (Scheme 19) [52-55].

\subsection{Biological profile}

The xanthine nucleus possesses numerous properties biologically. Xanthines are used widely as anti-asthmatics, adenosine receptor antagonists, and monoamine oxidase-B (MAOB) inhibitors in treating neurodegenerative disorders in the treatment of type-2 diabetes and many more conditions. Some of the xanthine nuclei drugs are already available in the market, while some are under different phases of clinical trials, as presented in Table 4 [56].

Table 4. Marketed drugs and drugs under clinical trial containing xanthine nucleus.

S. No.




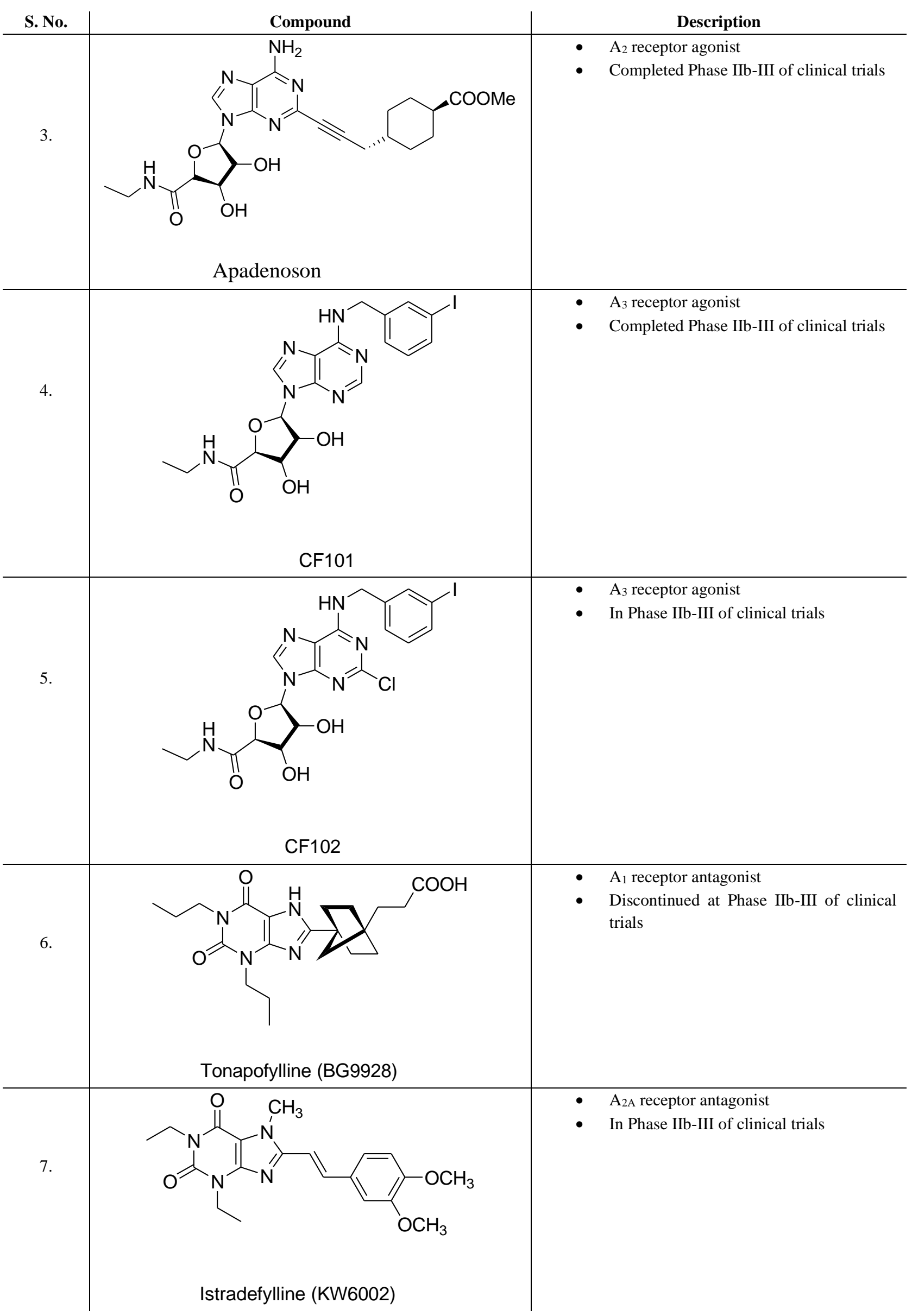




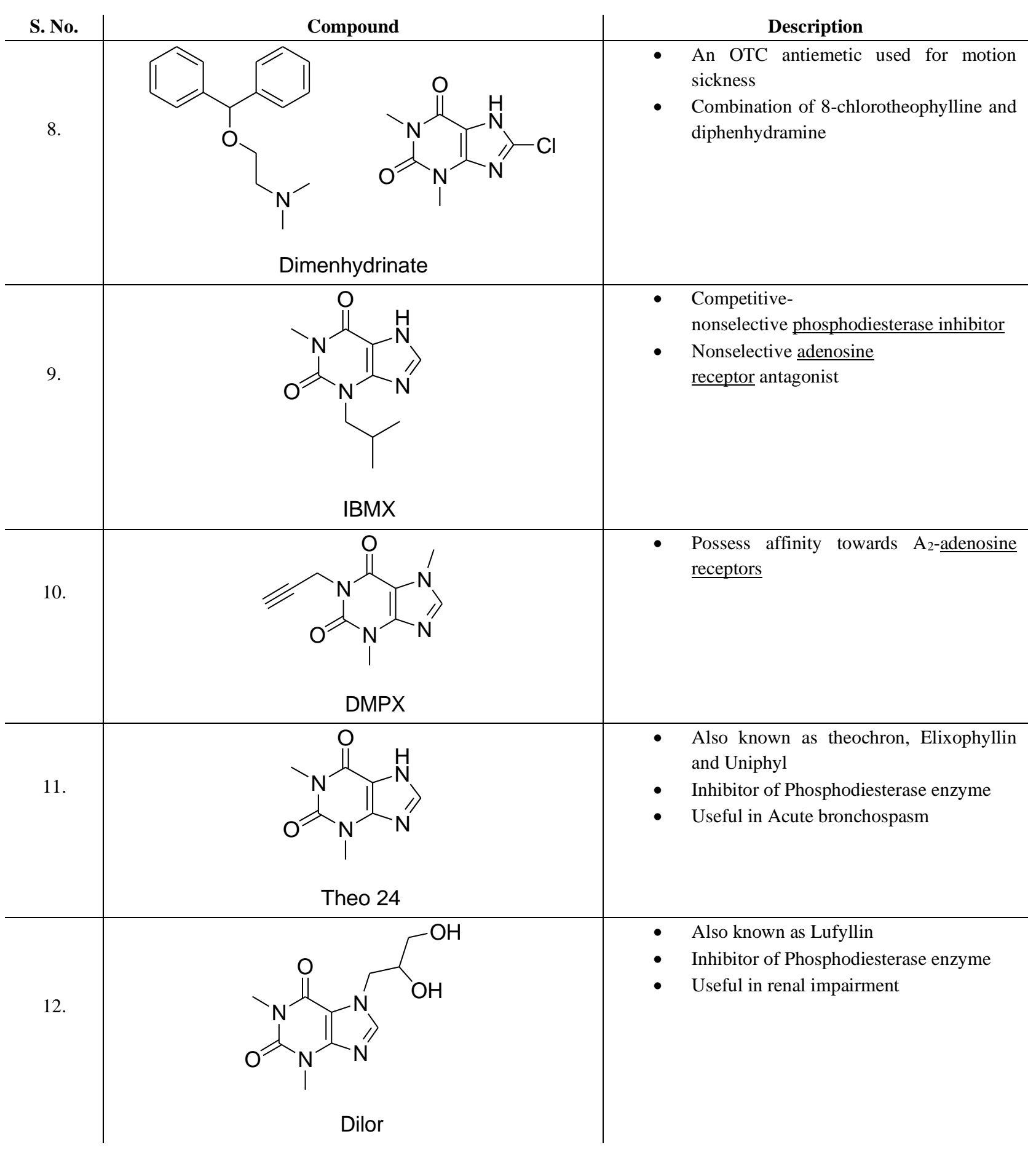

\subsection{Antibacterial agents.}

A series of 8-(substituted)-aryloxycaffeine were evaluated for their in vitro antibacterial activity compared to Staphylococcus aureus (KCTC 1916), Salmonella enteritidis (KCTC 12021), Salmonella typhimurium (KCTC 2515), and Bacillus subtilis (ATCC 6633). Among the series, the 8-(5-chloropyridin-3-yloxy)-1, 3, 7-trimethyl- $1 H$-purine-2, 6(3H,7H)-dione (91) displayed strong inhibitory activity $(\mathrm{MIC}=15.6 \mu \mathrm{g} / \mathrm{ml}$ ) against gram-negative (-) bacteria Salmonella enteritidis. The other three derivatives, 92-94, also showed excellent inhibitory activity with a value of $31.2 \mu \mathrm{g} / \mathrm{ml}$ against gram-negative (-) bacteria Salmonella enteritidis and gram-positive (+) bacteria Bacillus subtilis (Figure 2) [57]. 
<smiles>Cn1c(=O)c2c(nc(Oc3cncc(Cl)c3)n2C)n(C)c1=O</smiles>

(91)<smiles>Cn1c(=O)c2c(nc(Oc3cccnc3Cl)n2C)n(C)c1=O</smiles>

(93)<smiles>Cn1c(=O)c2c(nc(Oc3cccc(C=O)c3)n2C)n(C)c1=O</smiles>

(92)<smiles>Cn1c(=O)c2c(nc(Oc3cccc(Cl)n3)n2C)n(C)c1=O</smiles>

(94)

Figure 2. Xanthine nucleus containing compounds as antibacterial agents.

\subsection{DNA topoisomerase II inhibitors.}

Topo II inhibitory activity of 8-(substituted)-aryloxy-caffeine was calculated by assessing the recreation of supercoiled pBR322 plasmid DNA. Among all the caffeine derivatives, 1,3,7-trimethyl-8-(quinolin-8-yloxy)- $1 H$-purine-2,6(3H,7H)-dione (95) was the highly active inhibitor showing $28.42 \%$ and $48.92 \%$ inhibition as compared to $42.82 \%$ and $66.87 \%$ of etoposide at $20 \mu \mathrm{M}$ and $100 \mu \mathrm{M}$ concentration [58].

\subsection{Analgesics.}

The analgesic effect of a series of 8-(substituted)-aryloxy-caffeine derivatives was studied by their effect on motor activity in mice, their general behavior, and their effect on thermal pain. The phenoxy (96) and pyridine (97) substituted derivates showed an increase in locomotion percentage, while methylpyridine (98) and trifluoromethylpyridine (99) substituted derivatives showed analgesic activity without any central stimulation (Figure 3) [59].<smiles>Cn1c(=O)c2c(nc(Oc3cccc4cccnc34)n2C)n(C)c1=O</smiles>

(95)<smiles>Cn1c(=O)c2c(nc(Oc3ccccc3)n2C)n(C)c1=O</smiles>

(96)<smiles>Cn1c(=O)c2c(nc(Oc3ccccn3)n2C)n(C)c1=O</smiles>

(97)<smiles>Cc1cccc(Oc2nc3c(c(=O)n(C)c(=O)n3C)n2C)n1</smiles>

(98)<smiles>Cn1c(=O)c2c(nc(Oc3nc(C(F)(F)F)ccc3Cl)n2C)n(C)c1=O</smiles>

(99)

Figure 3. Xanthine nucleus containing compounds.

2.6. Monoamine oxidase-B (MAO-B) inhibitors.

MAO-B oxidizes dopamine in the brain. For each mole of dopamine oxidized, one mole of hydrogen peroxide $\left(\mathrm{H}_{2} \mathrm{O}_{2}\right)$ is produced, which interacts with free ions to form highly reactive 
hydroxyl radicals resulting in age-related neurodegenerative diseases such as Alzheimer's disease and Parkinson's disease [59]. Thus MAO-B inhibitors are useful in treating neurodegenerative disease [60,61].(E)-8-(3-chlorostyryl) caffeine (CSC, 100) found to be the promising agent with a good affinity for adenosine $\mathrm{A}_{2 \mathrm{~A}}$ receptor subtype and also MAO-B inhibitory potency. The further modifications of caffeinyl core of CSC and bioisosteric replacement of purine nitrogen atom at 9-position resulted in 9-deazaxanthines acting as both $\mathrm{A}_{2 \mathrm{~A}}$ antagonists and MAO-B inhibitors. The $p$-chlorostyryl derivative (101) of 9-deazaxanthine and benzyloxy (102) or phenylalkynyl (103) substituents replaced at 8-styryl portion of 100 resulted in compounds showing remarkable MAO-B inhibitory potency even higher than CSC [62]. Also, a series of (E,E)-8-(4-phenylbutadien-1-yl)caffeine analogs (104-107) were found as potent inhibitors of MAO-B (Figure 4) [63].<smiles>Cn1c(=O)c2c(nc(/C=C/c3cccc(Cl)c3)n2C)n(C)c1=O</smiles>

(100)<smiles>Cn1c(=O)c2c(cc(/C=C/c3ccc(Cl)cc3)n2C)n(C)c1=O</smiles>

(101)<smiles>CC#Cc1cc2c(c(=O)n(C)c(=O)n2C)n1C</smiles>

(103)<smiles>Cn1c(=O)c2c(nc(/C=C/C=C/c3ccccc3)n2C)n(C)c1=O</smiles>

(104)<smiles>Cn1c(=O)c2c(cc(OCc3ccc(Cl)cc3)n2C)n(C)c1=O</smiles>

(102)<smiles>Cn1c(=O)c2c(nc(/C=C/C=C/c3cccc(Cl)c3)n2C)n(C)c1=O</smiles>

(105)

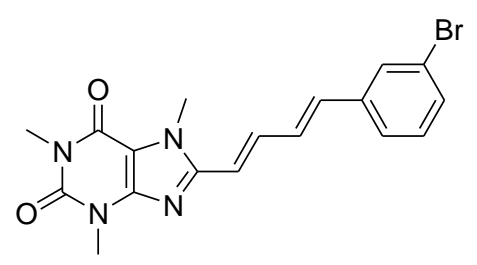

(106)

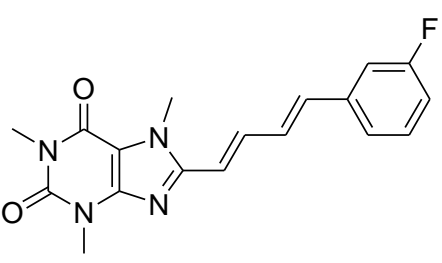

(107)

Figure 4. Xanthine nucleus contains compounds as MAO-B inhibitors.

\subsection{Anti-Parkinson's agents.}

Various $\mathrm{A}_{2 \mathrm{~A}}$ antagonists found to be useful in treating the symptoms of Parkinson's disease which lead to discovery of CSC [64], istradefylline (KW6002, 108) [65-67], KF-17837 (109) [68-70], DMPX (110) [71], DPMTX (111) [72], MSX-2 (112) [73-76], SCH 58261 (113) [77-79], ZM241385 (114) [80,81], CGS 15943 (115) [82] and ST1535 (116) [83-92]. They found to improve motor impairment and reduced "off" time when co-administered with levodopa (Figure 5) [93].

\subsection{Bronchodilators.}

Various 8-aryl or 8-cycloaryl substituted xanthines were found to be potent bronchodilators on isolated guinea-pig tracheal strips, which were precontracted by acetylcholine or histamine. 8-[1-(4-benzoylphenyl) ethyl]-1,3-dimethyl-3,7-dihydropurin-2,6dione (117) has some inhibitory effect on acetylcholine-induced precontractions as that of theophylline. The substitution of furan ring at 8-position of xanthine also gave compounds with significant inhibitory activity on the tracheal strips precontracted by histamine $(118,119)$. The substitution with morpholino- (120), piperidine- (121), and pyrimidine- (122) moieties also 
showed the considerable effect as bronchodilators. The compound 123 also had a similar effect as 121 (Figure 6) [94].

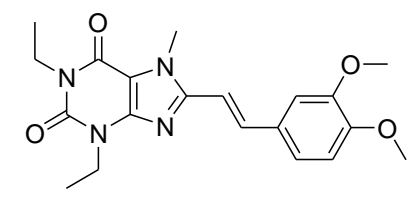

$(108)$<smiles>CCCn1c(=O)c2c(nc(/C=C/c3ccsc3)n2C)n(CCC)c1=O</smiles>

(111)<smiles>CCCn1c(=O)c2c(nc(/C=C/c3ccc(OC)c(OC)c3)n2C)n(CCC)c1=O</smiles>

(109)<smiles>C#CCn1c(=O)c2c(nc(/C=C/c3cccc(OC)c3)n2C)n(CCCO)c1=O</smiles>

(112)<smiles>C#CCn1c(=O)c2c(ncn2C)n(C)c1=O</smiles>

(110)<smiles>Nc1nc2c(cnn2CCc2ccccc2)c2nc(-c3ccco3)nn12</smiles>

(113)<smiles>Nc1nc(CCCc2ccc(O)cc2)nc2nc(-c3ccco3)nn12</smiles>

(114)

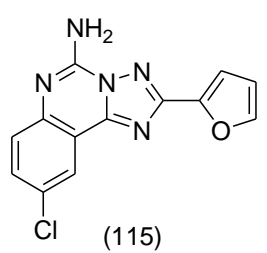

(115)<smiles>CCCCc1cc2c(nc1N)c(-n1nccn1)nn2C</smiles>

(116)

Figure 5. Xanthine nucleus containing compounds as Antiparkinson's agents.<smiles>CC(Cc1nc2c([nH]1)c(=O)n(C)c(=O)n2C)c1cccc(C(=O)c2ccccc2)c1</smiles>

(117)<smiles>Cn1c(=O)c2[nH]c(-c3ccc(-c4cccc(Cl)c4)o3)nc2n(C)c1=O</smiles>

(118)<smiles>Cn1c(=O)c2[nH]c(-c3ccc(-c4cc(Cl)cc([N+](=O)[O-])c4)o3)nc2n(C)c1=O</smiles>

(119)<smiles>Cn1c(=O)c2[nH]c(-c3ccc(C(=O)N4CCOCC4)cc3)nc2n(C)c1=O</smiles>

(120)<smiles>CC1CCCCN1OC(=O)c1ccc(-c2nc3c([nH]2)c(=O)n(C)c(=O)n3C)cc1</smiles><smiles>Cn1c(=O)c2[nH]c(-c3ccc(C(=O)N4CCN(CCO)CC4)cc3)nc2n(C)c1=O</smiles>

(122)

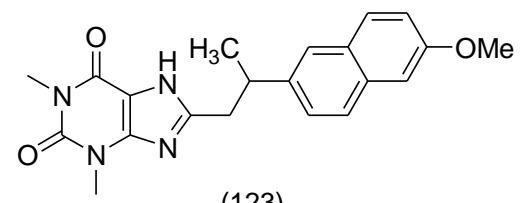

(123)

Figure 6. Xanthine nucleus contains compounds as bronchodilators.

\subsection{Dipeptidyl peptidase (DPP-4) inhibitors.}

DPP-4 inhibitors degrade various neuropeptides, peptide hormones, and cytokines such as glucagon-like peptides (GLP-1) and GIP. GLP-1 inhibits glucagon release from pancreatic $\alpha$ cells, reduces food intake, and retards gastric emptying. The inhibition of DPP-4 will improve glucose homeostasis. A novel, potent and selective DPP-4 inhibitor originated from the class of xanthine (BI1356, 124). Another 7-,8-substituted xanthine derivative (125) was discovered through high-throughput screening. Various other xanthine derivatives also showed considerable DPP-4 inhibitory activity against human DPP-4 derived preparation from Caco-2 
cells. The replacement of piperazine at C-8 for 3-aminopiperidine in 126 resulted in a tremendous increase in potency. The optimization at $N-7$ resulted in more potent compounds $(127,128)$, while further substitution at $N-1(129)$ in the case of 127 resulted in an additional increase in potency whose $(S)$-configuration was twice as potent as $(R)$-configuration (Figure 7) $[10]$.

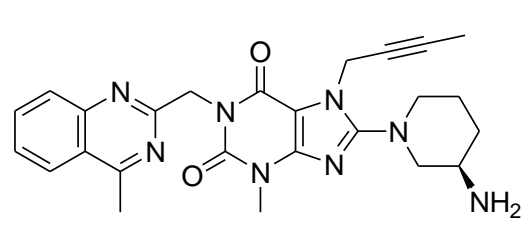

(124)<smiles>CC(C)=CCn1c(N2CCCC(N)C2)nc2c1c(=O)n(C)c(=O)n2C</smiles>

(127)<smiles>Cn1c(=O)[nH]c(=O)c2c1nc(N1CCNCC1)n2Cc1ccccc1</smiles>

$(125)$

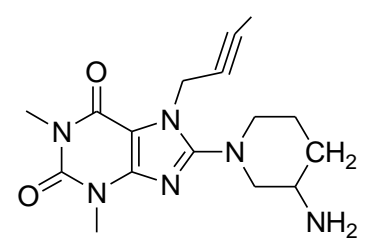

(128)<smiles>Cn1c(=O)c2c(nc(N3CCNCC3)n2Cc2ccccc2)n(C)c1=O</smiles>

(126)<smiles>CC(C)=CCn1c(N2CCCC(N)C2)nc2c1c(=O)n(CC(=O)c1ccccc1)c(=O)n2C</smiles>

(129)

Figure 7. Xanthine nucleus contains compounds as DPP-4 inhibitors.

\subsection{Kinase inhibitors.}

Xanthine analogs were also identified as potent kinase inhibitors against PI3Ks and also found to inhibit the proliferation in T47D tumor cells. Additionally, xanthine-based kinase inhibitors also showed significant fluorescence emission in a concentration-dependent response. The group was the first to disclose the importance of xanthine scaffolds as fluorophores. 8-acetamido substituted xanthine (130) showed the potent antiproliferative effect on tumor cells against MTT assay. Another xanthine derivative, 131, was also found to show an inhibitory effect on various kinases (Figure 8) [95-97].

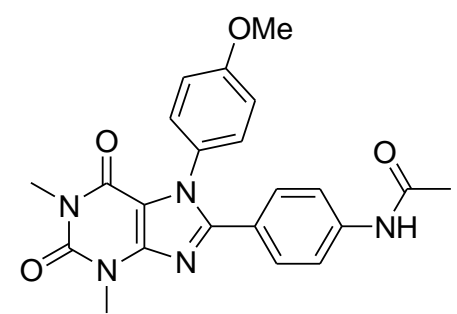

(130)

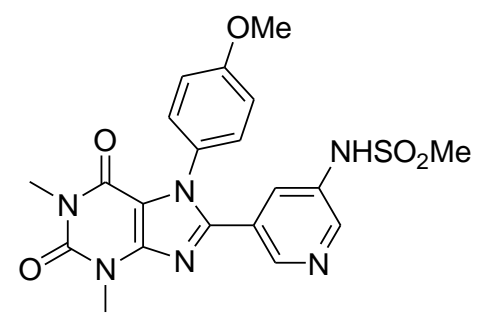

(131)

Figure 8. Xanthine nucleus contains compounds as Kinase inhibitors.

\subsection{Antiviral agents.}

Various antiviral agents are derivatives of uracil, a key compound for the synthesis of xanthine derivatives, such as zidovudine (AZT, 132) [98], stavudine (Zerit, 133) [99], abacavir (Ziagen, 134 [100] and 1-((2-hydroxyethoxy)methyl)-6-(phenylthio)thymine (HEPT,135) [101-103] and its derivatives. The xanthine derivative, i.e., Acyclovir (136), is also used clinically as an antiviral agent. The antiviral property is associated with either inhibiting the reverse transcription process of the virus replication or through DNA chain termination of viral DNA by being incorporated in the viral DNA chain (Figure 9) [104-106]. 
<smiles>Cc1cn(C2COCC23COC3)c(=O)[nH]c1=O</smiles>

(132)<smiles>Cc1cn(-c2ccc(CO)cc2)c(=O)[nH]c1=O</smiles>

(133)<smiles>Nc1nc(NC2CC2)c2ncn(C(CO)CCO)c2n1</smiles>

(134)<smiles>Cc1c(Sc2ccccc2)n(COCCO)c(=O)[nH]c1=O</smiles>

(135)<smiles>Nc1nc2c(ncn2CO)c(=O)[nH]1</smiles>

(136)

Figure 9. Xanthine nucleus contains compounds as Antiviral agents.

\subsection{Adenosine receptor antagonists.}

Adenosine plays an important role in asthma by activating A2B adenosine receptors on mast cells and bronchial smooth muscle cells, thus enhancing the degranulation of mast cells and releasing inflammatory cytokines. The antagonist of $\mathrm{A}_{2 \mathrm{~B}}$ adenosine receptors plays an important role as antiasthmatics. Various 1-,3- and 8-substituted xanthines possess affinity and selectivity for adenosine receptor subtypes $\left(A_{1}, A_{2 A}, A_{2 B}\right.$, and $\left.A_{3}\right)$ [107-109]. Several 3-furyl7-methylxanthine derivatives showed a high affinity towards human $\mathrm{A}_{2 \mathrm{~B}}$ receptors. 1-ethyl-3((furan-2-yl) methyl)-7-methyl-8-((thiophen-2-yl) methyl)-1H-purine-2, 6-(3H,7H)-dione (137) was found to be most active with a $K i$ value of $7.4 \mathrm{~nm}$ for $h \mathrm{~A}_{2 \mathrm{~B}}$ receptors among this series [46]. MRS-1754 (138) and CVT-5440 ( $K i=50 \mathrm{~nm}, 139)$ were also discovered as highaffinity $\mathrm{A}_{2 \mathrm{~B}}$ adenosine receptor antagonists with good selectivity [110]. Jacobson and coworkers reported a useful radioligand $\left[{ }^{3} \mathrm{H}\right] \mathrm{ZM} 241385$ (140) and XAC (141) for the study of the $\mathrm{A}_{2 \mathrm{~B}}$ adenosine receptor subtype [111-113].

Baraldi et al. synthesized a series of 8-heterocyclic xanthine derivatives, among which MRE2028F20 (142), MRE2029F20 (143), and MRE2030F20 (144) showed high affinity at A2B receptor subtypes and very good selectivity vs. other adenosine receptors (Figure 10) [37]. A2A adenosine receptors antagonists are also a major target for CNS drug delivery due to their interactions with D2 receptors. The lead compounds as A2A antagonists have been discovered as a clinical candidate for Parkinson's disease-bearing a xanthine skeleton [18,114-116]. Bansal et al. also reported a series of 8-(substituted-phenyl)-xanthines possessing binding affinity towards adenosine A2Areceptors. Among the disubstituted vanilloid, series compounds with methoxy group ortho to polar substituents at the 4th position of phenyl ring (145-147) possess a good binding affinity for A2A receptors. While in isovanilloid series, 1,3dimethyl-8-[4-methoxy-3-(2-morpholin-4-ylethoxy) phenylxanthine (148) found as most potent and active at $\mathrm{A} 2 \mathrm{~A}$ receptors $(\mathrm{Ki}=100 \mathrm{~nm})$ [27]. In the case of mono-substituted xanthines, compounds with diethylaminoethoxy substituent (149) emerged as the most potent towards A2A receptors. In this series, chloropropoxy phenyl substituted $(150, \mathrm{Ki}=45 \mathrm{~nm})$ and cyclopentyloxy derivative of 8 -substituted xanthine $(151, \mathrm{Ki}=72 \mathrm{~nm})$ also exhibited remarkable affinity and selectivity towards A2A receptors (Figure 11) [30,117]. 
<smiles>CCn1c(=O)c2c(nc(CC3=CC=CCS3)n2C)n(Cc2ccco2)c1=O</smiles>

(137)<smiles>CCCn1c(=O)c2[nH]c(-c3ccc(OCc4noc(-c5cccc(OC)c5)n4)cc3)nc2n(CCC)c1=O</smiles>

(139)<smiles>CCCn1c(=O)c2[nH]c(-c3ccc(OCC(=O)NCCN)cc3)nc2n(CCC)c1=O</smiles>

(141)<smiles>CCCn1c(=O)c2[nH]c(-c3cc(OCC(=O)NC4C=C5OCOC5=CC4)nn3C)nc2n(CCC)c1=O</smiles>

(143)<smiles>CCCn1c(=O)c2[nH]c(-c3ccc(OCC(=O)Nc4ccc(C)cc4)cc3)nc2n(CCC)c1=O</smiles>

(138)<smiles>Nc1nc(NCCc2ccc(O)cc2)nc2nc(-c3ccco3)nn12</smiles>

(140)<smiles>CCCn1c(=O)c2[nH]c(-c3cc(NC(=O)Cc4cc(OC)c(OC)c(OC)c4)nn3C)nc2n(CCC)c1=O</smiles>

(142)<smiles>CCCn1c(=O)c2[nH]c(-c3cc(OCC(=O)Nc4ccc(OC)c(OC)c4)nn3C)nc2n(CCC)c1=O</smiles>

(144)

Figure 10. Xanthine nucleus containing compounds as $\mathrm{A}_{2 \mathrm{~B}}$ adenosine receptor antagonist.<smiles>COc1ccc(-c2nc3c([nH]2)c(=O)n(C)c(=O)n3C)cc1OC</smiles>

$(145)$<smiles>CCCCNCCCOc1ccc(-c2nc3c([nH]2)c(=O)n(C)c(=O)n3C)cc1OC</smiles>

(147)

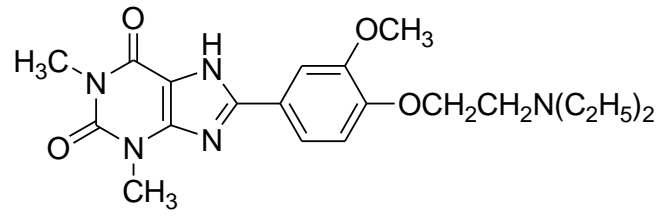

(146)<smiles>COc1ccc(-c2nc3c([nH]2)c(=O)n(C)c(=O)n3C)cc1OC</smiles>

(148)<smiles>CCNCCCOc1cccc(-c2nc3c([nH]2)c(=O)n(C)c(=O)n3C)c1</smiles>

Figure 11. Xanthine nucleus contains compounds as $A_{2 A}$ adenosine receptor antagonists. 
A series of 1,3,7-Triethylsubstituted xanthines were found to possess antagonistic properties at adenosine $A_{1}$ receptors, thus having the therapeutic potential to treat complex neurological disorders like Alzheimer's disease and Parkinson's disease. Among the series of substituted xanthines, 1,3,7-Triethyl-8-(3-phenylpropyl) xanthine (152), 1,3,7-Triethyl-8-(2phenylethyl) xanthine (153) and 1, 3, 7-Triethyl-8-(phenoxymethyl) xanthine (154) found to be potent and displayed the highest affinity against adenosine $A_{1}$ receptors in GTP shift assays performed with either rat cortical or whole-brain membranes expressing adenosine $\mathrm{A}_{1}$ receptors (Figure 12) [118, 119].<smiles>CCCCCC(C)(C)c1nc2c(c(=O)n(CC)c(=O)n2CC)n1CC</smiles>

(152)<smiles>CCCCCCCCCn1c(CC)nc2c1c(=O)n(CCC)c(=O)n2CC</smiles>

(153)<smiles>CCCCCOCc1nc2c(c(=O)n(CC)c(=O)n2CC)n1CC</smiles>

(154)

Figure 12. Xanthine nucleus contains compounds as $A_{1}$ adenosine receptor antagonists.

The various other xanthines usually used to treat asthma as given by WHO list of International Nonproprietary Names (INNs) are given in Table 5 [120].

Table 5. Various xanthines used to treat asthma.

\begin{tabular}{|c|c|c|}
\hline \\
\hline S. No. & Drug & Comments \\
\hline 1 & Albifylline & 1-(5-Hydroxy-5-methylhexyl)-3-methylxanthine \\
\hline 2 & Aminophylline & $\begin{array}{l}\text { A mixture of theophylline with ethylenediamine in a ratio of about } \\
85: 15 \text {, to increase the solubility of the xanthine, the ethylenediamine } \\
\text { may cause hypersensitivity reactions }\end{array}$ \\
\hline 3 & Bamifylline & 8-Benzyl-7-[2-(N-ethyl- $N$-2-hydroxyethylamino)ethyl]theophy- -lline \\
\hline 4 & Caffeine & Methyltheobromine \\
\hline 5 & Choline theophyllinate & Choline salt of theophylline \\
\hline 6 & Diprophylline & 7-(2,3-Dihydroxypropyl)1,3-dimethylxanthine \\
\hline 7 & Doxofylline & (1,3-Dioxolan-2-ylmethyl)theophylline \\
\hline 8 & Enprofylline & 3,7-Dihydro-3-propylxanthine \\
\hline 9 & Etofylline & 7-(2-Hydroxyethyl)-1,3-dimethylxanthine \\
\hline 10 & Heptaminol acephyllinate & A salt of theophylline-7-yl acetic acid \\
\hline 11 & Proxyphylline & 7-(2-Hydroxypropyl)-1,3-dimethylxanthine \\
\hline 12 & Pyridophylline & 2-(theophylline-7-yl)ethyl sulfate \\
\hline 13 & Theobromine & 3,7-Dimethylxanthine \\
\hline 14 & Theophylline & 1,3-Dimethylxanthine \\
\hline
\end{tabular}

In addition, the COVID-19 pandemic presents an unprecedented challenge to identify effective drugs for the treatment. Pentoxifylline, a xanthine derivative, is a well-known antiinflammatory and anti-oxidative molecule which may be beneficial for better clinical outcomes in COVID-19 patients. Along with the significant evidence and high safety profiles, xanthines offer a glimpse of considerations for future use as a potential adjuvant to COVID-19 treatment. However, additional clinical studies are required to confirm this speculation [121].

\section{Conclusions}

The importance, potency, and binding affinity of the substituted xanthine nucleus have been presented in this review. Xanthine and its derivatives are nowadays further explored for neurodegenerative disorders, mainly Parkinson's disease. The xanthines' 1-, 3- and 8-positions can be explored highly with different substitutions varying from increasing alkyl chain to aromatic or cyclic heteroaromatics to get potent and selective compounds. The $7^{\text {th }}$ position of 
the nucleus has also been considered for various biological targets. The xanthine nucleus possesses large diversity biologically, as clear from the literature cited in this review. Yet, there are areas and more biological targets to be explored in the direction of xanthine and its derivatives to get the most active and potent compounds.

\section{Funding}

This research received no external funding.

\section{Acknowledgments}

The authors are thankful to Banasthali Vidyapith, Banasthali, and Amity University, Haryana, for providing the necessary facilities.

\section{Conflict of interest}

The authors declare no conflict of interest.

\section{References}

1. Jacobson, K.A.; Kirk, K.L.; Padgett, W.L.; Daly, J.W. Functionalized Congeners of 1, 3-Dialkylxanthines: Preparation of Analogues with High Affinity for Adenosine Receptors. J. Med. Chem. 1985, 28, 1334-1340, https://doi.org/10.1021/jm00147a038.

2. Song, B.; Xiao, T.; Qi, X.; Li, L.N.; Qin, K.; Nian, S.; Hu, G.X.; Yu, Y.; Liang, G.; Ye, F. Design and Synthesis of 8-Substituted Benzamido-Phenylxanthine Derivatives as MAO-B Inhibitors. Bioorganic Med. Chem. Lett. 2012, 22, 1739-1742, https://doi.org/10.1016/j.bmcl.2011.12.094.

3. Janitschke, D; Lauer, A.A; Bachmann, C.M; Grimm, H.S; Hartmann, T; Grimm, M.O.W. Methylxanthines and Neurodegenerative Diseases: An Update. Nutrients. 2021, 28, 13, 803, https://doi.org/10.3390/nu13030803.

4. Shyamlal, B.R.K; Mathur, M.; Yadav, D.K.; Chaudhary, S. Microwave-assisted Modified Synthesis of C8Analogues of Naturally Occurring Methylxanthines: Synthesis, Biological Evaluation and Their Practical Applications. Fitoterapia, 2020, 143,104533, https://doi.org/10.1016/j.fitote.2020.104533.

5. Kasabova-Angelova, A.; Tzankova, D.; Mitkov, J.; Georgieva, M.; Tzankova, V.; Zlatkov, A.; KondevaBurdina, M. Xanthine Derivatives as Agents Affecting Non-dopaminergic Neuroprotection in Parkinson's Disease. Curr Med Chem., 2020, 27, 2021-2036, https://doi.org/10.2174/0929867325666180821153316.

6. Palacios, N.; Gao, X.; McCullough, M.L.; Schwarzschild, M.A.; Shah, R.; Gapstur, S.; Ascherio, A. Caffeine and Risk of Parkinson's Disease in a Large Cohort of Men and Women. Mov. Disord. 2012, 27, 1276-1282, https://doi.org/10.1002/mds.25076.

7. Popat, R.A.; Van Den Eeden, S.K.; Tanner, C.M.; Kamel, F.; Umbach, D.M.; Marder, K.; Mayeux, R.; Ritz, B.; Ross, G.W.; Petrovitch, H.; et al. Coffee, ADORA2A, and CYP1A2: The Caffeine Connection in Parkinson's Disease. Eur. J. Neurol. 2011, 18, 756-765, https://doi.org/10.1111/j.1468-1331.2011.03353.x.

8. Tam, D.N.H; Mostafa, E.M; Tu, V.L.; Rashidy, A.I; Matenoglou, E.; Kassem, M.; Soa, D.T.; Bayumi, A.; Emam, H.E.S.; Tran, L.; Dat, T.V.; Huy, N.T. Efficacy of chalcone and xanthine derivatives on lipase inhibition: A systematic review. Chem. Biol. Drug Des. 2020, 95, 205-214, https://doi.org/10.1111/cbdd.13626.

9. Rashad, A.Y.; Kassab, S.E.; Daabees, H.G.; Abdel Moneim, A.E.; Rostom, S.A.F. Febuxostat-Based Amides and Some Derived Heterocycles Targeting Xanthine Oxidase and COX inhibition. Synthesis, in vitro and in vivo Biological Evaluation, Molecular Modeling and In silico ADMET studies. Bioorg. Chem. 2021, 113, 104948, https://doi.org/10.1016/j.bioorg.2021.104948.

10. Cazzola, M.; Matera, M.G. The effect of doxofylline in asthma and COPD. Respir. Med. 2020, 164, 105904, https://doi.org/10.1016/j.rmed.2020.105904.

11. Li, J.; Li, Y.P.; Qin, F.Y.; Yan, Y.M.; Zhang, H.X.; Cheng, Y.X. Racemic xanthine and dihydroxydopamine conjugates from Cyclopelta parva and their COX-2 inhibitory activity. Fitoterapia 2020, 142,104534, https://doi.org/10.1016/j.fitote.2020.104534.

12. Bruns, R.F.; Fergus, J.H. Solubilities of Adenosine Antagonists Determined by Radioreceptor Assay. J. 
Pharm. Pharmacol. 1989, 41, 590-594, https://doi.org/10.1111/j.2042-7158.1989.tb06537.x.

13. Pobudkowska, A.; Domańska, U.; Kryska, J.A. The Physicochemical Properties and Solubility of Pharmaceuticals - Methyl Xanthines. J. Chem. Thermodyn. 2014, 79, 41-48, https://doi.org/10.1016/j.jct.2014.05.005.

14. Persson, C.G.A.; Andersson, K.E.; Kjellin, G. Effects of Enprofylline and Theophylline May Show the Role of Adenosine. Life Sci. 1986, 38, 1057-1072, https://doi.org/10.1016/0024-3205(86)90241-9.

15. Papesch, V.; Schroeder, E.F. Synthesis of 1-Mono- and 1,3-Di-Substituted 6-Aminouracils. Diuretic Activity. J. Org. Chem. 1951, 16, 1879-1890, https://doi.org/10.1021/jo50006a010.

16. Erickson, R.H.; Hiner, R.N.; Feeney, S.W.; Blake, P.R.; Rzeszotarski, W.J.; Hicks, R.P.; Costello, D.G.; Abreu, M.E. 1,3,8-Trisubstituted Xanthines. Effects of Substitution Pattern upon Adenosine Receptor A1/A2 Affinity. J. Med. Chem. 1991, 34, 1431-1435, https://doi.org/10.1021/jm00108a029.

17. Yoneda, F.; Matsumoto, S.; Higuchi, M. New Synthesis of Purines by the Reaction of Diethyl Azodicarboxylate with 6-Alkylaminouracils. J. Chem. Soc. Chem. Commun. 1975, 146-147, https://doi.org/10.1039/C39750000146.

18. Labeaume, P.; Dong, M.; Sitkovsky, M.; Jones, E. V.; Thomas, R.; Sadler, S.; Kallmerten, A.E.; Jones, G.B. An Efficient Route to Xanthine Based A2A Adenosine Receptor Antagonists and Functional Derivatives. Org. Biomol. Chem. 2010, 8, 4155-4157, https://doi.org/10.1039/c003382k.

19. Załuski, M.; Schabikowski, J.; Jaśko, P.; Bryła, A.; Olejarz-Maciej, A.; Kaleta, M.; Głuch-Lutwin, M.; Brockmann, A.; Hinz, S.; Zygmunt, M.; Kuder, K.; Latacz, G.; Vielmuth, C.; Müller, C.E.; KiećKononowicz, K. 8-Benzylaminoxanthine Scaffold Variations for Selective Ligands Acting On Adenosine A2A receptors. Design, Synthesis and Biological Evaluation. Bioorg. Chem., 2020, 101, 104033, https://doi.org/10.1016/j.bioorg.2020.104033.

20. Das, B.; Holla, H.; Srinivas, Y. Efficient (Bromodimethyl)Sulfonium Bromide Mediated Synthesis of Benzimidazoles. Tetrahedron Lett. 2007, 48, 61-64, https://doi.org/10.1016/j.tetlet.2006.11.018.

21. Choudhury, L.H. Bromodimethylsulfonium Bromide (BDMS): A Versatile Reagent in Organic Synthesis. Synlett 2006, 2006, 1619-1620, https://doi.org/10.1055/s-2006-941579.

22. Khan, A.T.; Ali, M.A.; Goswami, P.; Choudhury, L.H. A Mild and Regioselective Method for $\alpha$-Bromination of $\beta$-Keto Esters and 1,3-Diketones Using Bromodimethylsulfonium Bromide (BDMS). J. Org. Chem. 2006, 71, 8961-8963, https://doi.org/10.1021/jo061501r.

23. Das, B.; Ramu, R.; Ravikanth, B.; Reddy, K.R. (Bromodimethyl)Sulfonium Bromide Catalyzed One-Pot Synthesis of $\alpha$-Aminonitriles. Synthesis (Stuttg). 2006, 2006, 1419-1422, https://doi.org/10.1055/s-2006926421.

24. Li, G.; Meng, B.; Yuan, B.; Huan, Y.; Zhou, T.; Jiang, Q.; Lei, L.; Sheng, L.; Wang, W.; Gong, N.; Lu, Y.; Ma, C.; Li, Y.; Shen, Z.; Huang, H. The Optimization of Xanthine Derivatives Leading to HBK001 Hydrochloride as a Potent Dual Ligand Targeting DPP-IV and GPR119. Eur. J. Med. Chem. 2020, 88, 112017, https://doi.org/10.1016/j.ejmech.2019.112017.

25. Yan, L.; Müller, C.E. Preparation, Properties, Reactions, and Adenosine Receptor Affinities of Sulfophenylxanthine Nitrophenyl Esters: Toward the Development of Sulfonic Acid Prodrugs with Peroral Bioavailability. J. Med. Chem. 2004, 47, 1031-1043, https://doi.org/10.1021/jm0310030.

26. Yan, L.; Bertarelli, D.C.G.; Hayallah, A.M.; Meyer, H.; Klotz, K.N.; Müller, C.E. A New Synthesis of Sulfonamides by Aminolysis of P-Nitrophenylsulfonates Yielding Potent and Selective Adenosine A2B Receptor Antagonists. J. Med. Chem. 2006, 49, 4384-4391, https://doi.org/10.1021/jm060277v.

27. Bansal, R.; Kumar, G.; Gandhi, D.; Young, L.C.; Harvey, A.L. Synthesis of a Series of 8-(SubstitutedPhenyl)Xanthines and a Study on the Effects of Substitution Pattern of Phenyl Substituents on Affinity for Adenosine A1 and A2A Receptors. Eur. J. Med. Chem. 2009, 44, 2122-2127, https://doi.org/10.1016/j.ejmech.2008.10.017.

28. Bansal, R.; Narang, G.; Zimmer, C.; Hartmann, R.W. Synthesis of Some Imidazolyl-Substituted 2Benzylidene Indanone Derivatives as Potent Aromatase Inhibitors for Breast Cancer Therapy. Med. Chem. Res. 2011, 20, 661-669, https://doi.org/10.1007/s00044-010-9368-4.

29. Blicke, F.F.; Godt, H.C. Reactions of 1,3-Dimethyl-5,6-Diaminouracil. J. Am. Chem. Soc. 1954, 76, 27982800, https://doi.org/10.1021/ja01639a058.

30. Yadav, R.; Bansal, R.; Kachler, S.; Klotz, K.N. Novel 8-(p-Substituted-Phenyl/Benzyl)Xanthines with Selectivity for the A2A Adenosine Receptor Possess Bronchospasmolytic Activity. Eur. J. Med. Chem. 2014, 75, 327-335, https://doi.org/10.1016/j.ejmech.2014.01.045.

31. Bansal, R.; Kumar, G.; Gandhi, D.; Young, L.C.; Harvey, A.L. Synthesis of a New Series of 1H-Imidazol-1- 
Yl Substituted 8-Phenylxanthines as Adenosine Receptor Ligands. Chem. Biodivers. 2011, 8, 1290-1300, https://doi.org/10.1002/cbdv.201000141.

32. Traxler, P.M.; Wacker, O.; Bach, H.L.; Geissler, J.F.; Kump, W.; Meyer, T.; Regenass, U.; Roesel, J.L.; Lydon, N. Sulfonylbenzoyl-Nitrostyrenes: Potential Bisubstrate Type Inhibitors of the EGF-Receptor Tyrosine Protein Kinase. J. Med. Chem. 1991, 34, 2328-2337, https://doi.org/10.1021/jm00112a003.

33. Müller, C.E.; Shi, D.; Manning, M.; Daly, J.W. Synthesis of Paraxanthine Analogs (1,7-Disubstituted Xanthines) and Other Xanthines Unsubstituted at the 3-Position: Structure-Activity Relationships at Adenosine Receptors. J. Med. Chem. 1993, 36, 3341-3349, https://doi.org/10.1021/jm00074a015.

34. Everard, B.A.; Mills, J.A. Methods of Resolution. Part II. N-(-)-Menthyl-p-Sulphamylbenzoic Acid. J. Chem. Soc. 1950, 3386-3389, https://doi.org/10.1039/JR9500003386.

35. Datta, S.K.; Grundmann, C.; Bhattacharyya, N.K. An Abnormal Schmidt Reaction: 4,5-Dihydro-1H-1Benzazepin-2(3H)-One from $\gamma$-Phenylbutyric acid. J. Chem. Soc. C Org. 1970, 2058-2060, https://doi.org/10.1039/J39700002058.

36. Müller, C.E. Formation of Oxazolo[3,2-a]Purinones from Propynyluracils. J. Org. Chem. 1994, 59, 19281929, https://doi.org/10.1021/jo00086a058.

37. Baraldi, P.G.; Tabrizi, M.A.; Preti, D.; Bovero, A.; Romagnoli, R.; Fruttarolo, F.; Zaid, N.A.; Moorman, A.R.; Varani, K.; Gessi, S.; et al. Design, Synthesis, and Biological Evaluation of New 8-Heterocyclic Xanthine Derivatives as Highly Potent and Selective Human A2B Adenosine Receptor Antagonists. J. Med. Chem. 2004, 47, 1434-1447, https://doi.org/10.1021/jm0309654.

38. Senda, S.; Suzui, A.; Honda, M.; Fujimura, H. Uracil Derivatives and Related Compounds.III1) 5-Amino-1, 3, 6-Trialkyluracil Derivatives. (1). Chem. Pharm. Bull. 1958, 6, 482-487, https://doi.org/10.1248/cpb.6.482.

39. Papesch, V.; Dodson, R.M. Pyrimido[5,4-d][1,2,3]Triazines. J. Org. Chem. 1963, 28, 1329-1331, https://doi.org/10.1021/jo01040a043.

40. Stefanachi, A.; Leonetti, F.; Cappa, A.; Carotti, A. Fast and Highly Efficient One-Pot Synthesis of 9Deazaxanthines. Tetrahedron Lett. 2003, 44, 2121-2123, https://doi.org/10.1016/S0040-4039(03)00173-4.

41. Carotti, A.; Cadavid, M.I.; Centeno, N.B.; Esteve, C.; Loza, M.I.; Martinez, A.; Nieto, R.; Raviña, E.; Sanz, F.; Segarra, V.; et al. Design, Synthesis, and Structure-Activity Relationships of 1-,3-,8-, and 9-Substituted9-Deazaxanthines at the Human A2B Adenosine Receptor. J. Med. Chem. 2006, 49, 282-299, https://doi.org/10.1021/jm0506221.

42. Li, S.Y.; Zhang, T.J.; Wu, Q.X.; Olounfeh, K.M.; Zhang, Y.; Meng, F.H. Synthesis and Biological Evaluation of 5-benzyl-3-pyridyl-1H-1,2,4-triazole Derivatives as Xanthine Oxidase Inhibitors. Med. Chem. 2020, 16,119-127, https://doi.org/10.2174/1573406415666190409112209.

43. Kim, S.A.; Marshall, M.A.; Melman, N.; Kim, H.S.; Müller, C.E.; Linden, J.; Jacobson, K.A. StructureActivity Relationships at Human and Rat A2B Adenosine Receptors of Xanthine Derivatives Substituted at the 1-, 3-, 7-, and 8-Positions. J. Med. Chem. 2002, 45, 2131-2138, https://doi.org/10.1021/jm0104318.

44. Nieto, M.I.; Balo, M.C.; Brea, J.; Caamaño, O.; Cadavid, M.I.; Fernández, F.; Mera, X.G.; López, C.; Rodríguez-Borges, J.E. Synthesis of Novel 1-Alkyl-8-Substituted-3-(3-Methoxypropyl) Xanthines as Putative A2B Receptor Antagonists. Bioorganic Med. Chem. 2009, 17, 3426-3432, https://doi.org/10.1016/j.bmc.2009.03.029.

45. Muller, C.E.; Sandoval-Ramirez, J. A New Versatile Synthesis of Xanthines with Variable Substituents in the 1-, 3-, 7- and 8-Positions. Synthesis (Stuttg). 1995, 1995, 1295-1299, https://doi.org/10.1055/s-19954082.

46. Balo, M.C.; Brea, J.; Caamaño, O.; Fernández, F.; García-Mera, X.; López, C.; Loza, M.I.; Nieto, M.I.; Rodríguez-Borges, J.E. Synthesis and Pharmacological Evaluation of Novel 1- and 8-Substituted-3-Furfuryl Xanthines as Adenosine Receptor Antagonists. Bioorganic Med. Chem. 2009, 17, 6755-6760, https://doi.org/10.1016/j.bmc.2009.07.034.

47. Dong, M.; Sitkovsky, M.; Kallmerten, A.E.; Jones, G.B. Synthesis of 8-Substituted Xanthines via 5,6Diaminouracils: An Efficient Route to A2A Adenosine Receptor Antagonists. Tetrahedron Lett. 2008, 49, 4633-4635, https://doi.org/10.1016/j.tetlet.2008.05.071.

48. Thomas, R.; Lee, J.; Chevalier, V.; Sadler, S.; Selesniemi, K.; Hatfield, S.; Sitkovsky, M.; Ondrechen, M.J.; Jones, G.B. Design and Evaluation of Xanthine Based Adenosine Receptor Antagonists: Potential Hypoxia Targeted Immunotherapies. Bioorganic Med. Chem. 2013, 21, 7453-7464, https://doi.org/10.1016/j.bmc.2013.09.043.

49. Kadi, A.A.; El-Tahir, K.E.H.; Jahng, Y.; Motiur Rahman, A.F.M. Synthesis, biological evaluation and Structure Activity Relationships (SARs) study of 8-(substituted)aryloxycaffeine. Arab. J. Chem. 2019, 12, 
2356-2364, https://doi.org/10.1016/j.arabjc.2015.02.021.

50. Loux, H.M.; Falco, E.A.; Hitchings, G.H.; Taylor, E.C. Pyrimidopteridines by Oxidative Self-Condensation of Aminopyrimidines. J. Am. Chem. Soc. 1955, 77, 2243-2248, https://doi.org/10.1021/ja01613a066.

51. Müller, C.E.; Thorand, M.; Qurishi, R.; Diekmann, M.; Jacobson, K.A.; Padgett, W.L.; Daly, J.W. Imidazo[2,1-i]Purin-5-Ones and Related Tricyclic Water-Soluble Purine Derivatives: Potent A2A- and A3Adenosine Receptor Antagonistst. J. Med. Chem. 2002, 45, 3440-3450, https://doi.org/10.1021/jm011093d.

52. Fuchs, H.; Gottlieb, M.; Pfleiderer, W. Cheminform abstract: Purines, XII. Cyclization of 4-Alkylamino-5Nitrosouracils and Synthesis of 8-Substituted Xanthines and Bis(Theophyllin-8-yl)alkane Derivatives. Chem. Informationsd. 1978, 9, https://doi.org/10.1002/chin.197822203.

53. Rink, H. Solid-Phase Synthesis of Protected Peptide Fragments Using a Trialkoxy-Diphenyl-Methylester Resin. Tetrahedron Lett. 1987, 28, 3787-3790, https://doi.org/10.1016/S0040-4039(00)96384-6.

54. Heizmann, G.; Eberle, A.N. Xanthines as a Scaffold for Molecular Diversity. Mol. Divers. 1997, 2, 171-174, https://doi.org/10.1007/BF01682205.

55. Goldner, H.; Dietz, G.; Carstens, E. Neue Reaktionen Mit Nitrosouracilderivaten, VI. Die Oxydation von 5Nitroso-uracilen. Justus Liebigs Ann. Chem. 1966, 699, 145-152, https://doi.org/10.1002/jlac.19666990115.

56. Chen, J.F.; Eltzschig, H.K.; Fredholm, B.B. Adenosine Receptors as Drug Targets-What Are the Challenges? Nat. Rev. Drug Discov. 2013, 12, 265-286, https://doi.org/10.1038/nrd3955.

57. Kadi, A.A.; El-Tahir, K.E.H.; Jahng, Y.; Rahman, A.F.M.M. Synthesis, Biological Evaluation and Structure Activity Relationships (SARs) Study of 8-(Substituted)Aryloxycaffeine. Arab. J. Chem. 2019, 12, 23562364, https://doi.org/10.1016/j.arabjc.2015.02.021.

58. Wu, C.C.; Huang, K.F.; Yang, T.Y.; Li, Y.L.; Wen, C.L.; Hsu, S.L.; Chen, T.H. The Topoisomerase 1 Inhibitor Austrobailignan-1 Isolated from Koelreuteria henryi Induces a G2/M-Phase Arrest and Cell Death Independently of p53 in Non-Small Cell Lung Cancer Cells. PLoS One. 2015, 10, e0132052, https://doi.org/10.1371/journal.pone.0132052.

59. Barnham, K.J.; Masters, C.L.; Bush, A.I. Neurodegenerative Diseases and Oxidatives Stress. Nat. Rev. Drug Discov. 2004, 3, 205-214, https://doi.org/10.1038/nrd1330.

60. Youdim, M.B.H.; Edmondson, D.; Tipton, K.F. The Therapeutic Potential of Monoamine Oxidase Inhibitors. Nat. Rev. Neurosci. 2006, 7, 295-309, https://doi.org/10.1038/nrn1883.

61. Riederer, P.; Lachenmayer, L.; Laux, G. Clinical Applications of MAO-Inhibitors. Curr. Med. Chem. 2012, 11, 2033-2043, https://doi.org/10.2174/0929867043364775.

62. Rivara, S.; Piersanti, G.; Bartoccini, F.; Diamantini, G.; Pala, D.; Riccioni, T.; Stasi, M.A.; Cabri, W.; Borsini, F.; Mor, M.; et al. Synthesis of (E)-8-(3-Chlorostyryl)Caffeine Analogues Leading to 9-Deazaxanthine Derivatives as Dual A2A Antagonists/MAO-B Inhibitors. J. Med. Chem. 2013, 56, 1247-1261, https://doi.org/10.1021/jm301686s.

63. Pretorius, J.; Malan, S.F.; Castagnoli, N.; Bergh, J.J.; Petzer, J.P. Dual Inhibition of Monoamine Oxidase B and Antagonism of the Adenosine A2A Receptor by (E,E)-8-(4-Phenylbutadien-1-Yl)Caffeine Analogues. Bioorganic Med. Chem. 2008, 16, 8676-8684, https://doi.org/10.1016/j.bmc.2008.07.088.

64. Jacobson, K.A.; Gallo-Rodriguez, C.; Melman, N.; Fischer, B.; Maillard, M.; van Bergen, A.; van Galen, P.J.M.; Karton, Y. Structure-Activity Relationships of 8-Styrylxanthines as A2-Selective Adenosine Antagonists. J. Med. Chem. 1993, 36, 1333-1342, https://doi.org/10.1021/jm00062a005.

65. Shimada, J.; Koike, N.; Nonaka, H.; Shiozaki, S.; Yanagawa, K.; Kanda, T.; Kobayashi, H.; Ichimura, M.; Nakamura, J.; Kase, H.; et al. Adenosine A(2A) Antagonists with Potent Anti-Cataleptic Activity. Bioorganic Med. Chem. Lett. 1997, 7, 2349-2352, https://doi.org/10.1016/S0960-894X(97)00440-X.

66. Shiozaki, S.; Ichikawa, S.; Nakamura, J.; Kitamura, S.; Yamada, K.; Kuwana, Y. Actions of Adenosine A(2A) Receptor Antagonist KW-6002 on Drug-Induced Catalepsy and Hypokinesia Caused by Reserpine or MPTP. Psychopharmacology (Berl). 1999, 147, 90-95, https://doi.org/10.1007/s002130051146.

67. Kase, H. Industry Forum: Progress in Pursuit of Therapeutic A2A Antagonists - The Adenosine A2A Receptor Selective Antagonist KW6002: Research and Development toward a Novel Nondopaminergic Therapy for Parkinson's Disease. Neurology 2003, 61, S97--S100, https://doi.org/10.1212/01.wnl.0000095219.22086.31.

68. Shimada, J.; Suzuki, F.; Nonaka, H.; Ishii, A.; Ichikawa, S. (E)-1,3-Dialkyl-7-Methyl-8-(3,4,5Trimethoxystyryl) Xanthines: Potent and Selective Adenosine A2 Antagonists. J. Med. Chem. 1992, 35, 2342-2345, https://doi.org/10.1021/jm00090a027.

69. Nonaka, Y.; Shimada, J.; Nonaka, H.; Koike, N.; Aoki, N.; Kobayashi, H.; Kase, H.; Yamaguchi, K.; Suzuki, F. Photoisomerization of a Potent and Selective Adenosine A2 Antagonist, (E)-1,3-Dipropyl-8-(3,4- 
Dimethoxystyryl)-7-Methylxanthine. J. Med. Chem. 1993, 36, 3731-3733, https://doi.org/10.1021/jm00075a031.

70. Correa, M.; Wisniecki, A.; Betz, A.; Dobson, D.R.; O'Neill, M.F.; O'Neill, M.J.; Salamone, J.D. The Adenosine A2A Antagonist KF17837 Reverses the Locomotor Suppression and Tremulous Jaw Movements Induced by Haloperidol in Rats: Possible Relevance to Parkinsonism. Behav. Brain Res. 2004, 148, 47-54, https://doi.org/10.1016/S0166-4328(03)00178-5.

71. Seale, T.W.; Abla, K.A.; Shamim, M.T.; Carney, J.M.; Daly, J.W. 3,7-Dimethyl-1-Propargylxanthine: A Potent and Selective in vivo Antagonist of Adenosine Analogs. Life Sci. 1988, 43, 1671-1684, https://doi.org/10.1016/0024-3205(88)90478-X.

72. Sauer, R.; Maurinsh, J.; Reith, U.; Fülle, F.; Klotz, K.N.; Müller, C.E. Water-Soluble Phosphate Prodrugs of 1-Propargyl-8-Styrylxanthine Derivatives, A2(A)-Selective Adenosine Receptor Antagonists. J. Med. Chem. 2000, 43, 440-448, https://doi.org/10.1021/jm9911480.

73. Hockemeyer, J.; Burbiel, J.C.; Müller, C.E. Multigram-Scale Syntheses, Stability, and Photoreactions of A2A Adenosine Receptor Antagonists with 8-Styrylxanthine Structure: Potential Drugs for Parkinson's Disease. $J$. Org. Chem. 2004, 69, 3308-3318, https://doi.org/10.1021/jo035857.

74. Vollmann, K.; Qurishi, R.; Hockemeyer, J.; Müller, C.E. Synthesis and Properties of a New Water-Soluble Prodrug of the Adenosine A2A Receptor Antagonist MSX-2. Molecules 2008, 13, 348-359, https://doi.org/10.3390/molecules13020348.

75. Yang, M.; Soohoo, D.; Soelaiman, S.; Kalla, R.; Zablocki, J.; Chu, N.; Leung, K.; Yao, L.; Diamond, I.; Belardinelli, L.; et al. Characterization of the Potency, Selectivity, and Pharmacokinetic Profile for Six Adenosine A2A Receptor Antagonists. Naunyn. Schmiedebergs. Arch. Pharmacol. 2007, 375, 133-144, https://doi.org/10.1007/s00210-007-0135-0.

76. Baraldi, P.G.; Manfredini, S.; Simoni, D.; Zappaterra, L.; Zocchi, C.; Dionisotti, S.; Ongini, E. Synthesis of New Pyrazolo[4,3-e]1,2,4-Triazolo[1,5-c] Pyrimidine and 1,2,3-Triazolo[4,5-e]1,2,4-Triazolo[1,5-c] Pyrimidine Displaying Potent and Selective Activity as A2a Adenosine Receptor Antagonists. Bioorganic Med. Chem. Lett. 1994, 4, 2539-2544, https://doi.org/10.1016/S0960-894X(01)80279-1.

77. Zocchi, C.; Ongini, E.; Conti, A.; Ferrara, S.; Negretti, A.; Dionisotti, S. In vitro Pharmacology of SCH 58261, a New Potent and Selective A2a Adenosine Receptor Antagonist. Pharmacol. Res. 1995, 31, 202, https://doi.org/10.1016/1043-6618(95)87066-0.

78. El-Kalyoubi, S; Agili, F. Synthesis, In silico Prediction and In vitro Evaluation of Antitumor Activities of Novel Pyrido[2,3-d]pyrimidine, Xanthine and Lumazine Derivatives. Molecules 2020, 25, 5205, https://doi.org/10.3390/molecules25215205.

79. Baraldi, P.G.; Fruttarolo, F.; Tabrizi, M.A.; Preti, D.; Romagnoli, R.; El-Kashef, H.; Moorman, A.; Varani, K.; Gessi, S.; Merighi, S.; et al. Design, Synthesis, and Biological Evaluation of C9- and C2-Substituted Pyrazolo[4,3-e]-1,2,4-Triazolo[1,5-c]Pyrimidines as New A2A and A3 Adenosine Receptors Antagonists. $J$. Med. Chem. 2003, 46, 1229-1241, https://doi.org/10.1021/jm021023m.

80. Caulkett, P.W.R.; Jones, G.; McPartlin, M.; Renshaw, N.D.; Stewart, S.K.; Wright, B. Adenine Isosteres with Bridgehead Nitrogen. Part 1. Two Independent Syntheses of the [1,2,4]Triazolo[1,5-a] [1,3,5]Triazine Ring System Leading to a Range of Substituents in the 2, 5 and 7 Positions. J. Chem. Soc. Perkin Trans. 1 1995, 801-808, https://doi.org/10.1039/p19950000801.

81. Poucher, S.M.; Keddie, J.R.; Singh, P.; Stoggall, S.M.; Caulkett, P.W.R.; Jones, G.; Collis, M.G. The in vitro Pharmacology of ZM 241385, a Potent, Non-xanthine, A2a Selective Adenosine Receptor Antagonist. Br. J. Pharmacol. 1995, 115, 1096-1102, https://doi.org/10.1111/j.1476-5381.1995.tb15923.x.

82. Francis, J.E.; Cash, W.D.; Psychoyos, S.; Ghai, G.; Wenk, P.; Friedmann, R.C.; Atkins, C.; Warren, V.; Furness, P.; Hyun, J.L.; et al. Structure-Activity Profile of a Series of Novel Triazoloquinazoline Adenosine Antagonists. J. Med. Chem. 1988, 31, 1014-1020, https://doi.org/10.1021/jm00400a022.

83. Minetti, P.; Tinti, M.O.; Carminati, P.; Castorina, M.; Di Cesare, M.A.; Di Serio, S.; Gallo, G.; Ghirardi, O.; Giorgi, F.; Giorgi, L.; et al. 2-n-Butyl-9-Methyl-8-[1,2,3]Triazol-2-Y1-9H-Purin-6-Ylamine and Analogues as A2A Adenosine Receptor Antagonists. Design, Synthesis, and Pharmacological Characterization. J. Med. Chem. 2005, 48, 6887-6896, https://doi.org/10.1021/jm058018d.

84. Rose, S.; Jackson, M.J.; Smith, L.A.; Stockwell, K.; Johnson, L.; Carminati, P.; Jenner, P. The Novel Adenosine A2a Receptor Antagonist ST1535 Potentiates the Effects of a Threshold Dose of L-DOPA in MPTP Treated Common Marmosets. Eur. J. Pharmacol. 2006, 546, 82-87, https://doi.org/10.1016/j.ejphar.2006.07.017.

85. Tozzi, A.; Tscherter, A.; Belcastro, V.; Tantucci, M.; Costa, C.; Picconi, B.; Centonze, D.; Calabresi, P.; 
Borsini, F. Interaction of A2A Adenosine and D2 Dopamine Receptors Modulates Corticostriatal $\begin{array}{lllll}\text { Glutamatergic } & \text { Transmission. } & \text { Neuropharmacology } & \mathbf{2 0 0 7}, & \text { 783-789, }\end{array}$ https://doi.org/10.1016/j.neuropharm.2007.08.006.

86. Tronci, E.; Simola, N.; Borsini, F.; Schintu, N.; Frau, L.; Carminati, P.; Morelli, M. Characterization of the Antiparkinsonian Effects of the New Adenosine A2A Receptor Antagonist ST1535: Acute and Subchronic Studies in Rats. Eur. J. Pharmacol. 2007, 566, 94-102, https://doi.org/10.1016/j.ejphar.2007.03.021.

87. Rose, S.; Ramsay Croft, N.; Jenner, P. The Novel Adenosine A2a Antagonist ST1535 Potentiates the Effects of a Threshold Dose of L-Dopa in Unilaterally 6-OHDA-Lesioned Rats. Brain Res. 2007, 1133, 110-114, https://doi.org/10.1016/j.brainres.2006.10.038.

88. Pinna, A.; Pontis, S.; Borsini, F.; Morelli, M. Adenosine A2A Receptor Antagonists Improve Deficits in Initiation of Movement and Sensory Motor Integration in the Unilateral 6-Hydroxydopamine Rat Model of Parkinson's Disease. Synapse 2007, 61, 606-614, https://doi.org/10.1002/syn.20410.

89. Galluzzo, M.; Pintor, A.; Pèzzola, A.; Grieco, R.; Borsini, F.; Popoli, P. Behavioural and Neurochemical Characterization of the Adenosine A2A Receptor Antagonist ST1535. Eur. J. Pharmacol. 2008, 579, 149152, https://doi.org/10.1016/j.ejphar.2007.10.057.

90. Belcastro, V.; Tozzi, A.; Tantucci, M.; Costa, C.; Di Filippo, M.; Autuori, A.; Picconi, B.; Siliquini, S.; Luchetti, E.; Borsini, F.; et al. A2A Adenosine Receptor Antagonists Protect the Striatum against RotenoneInduced Neurotoxicity. Exp. Neurol. 2009, 217, 231-234, https://doi.org/10.1016/j.expneurol.2009.01.010.

91. Frau, L.; Borsini, F.; Wardas, J.; Khairnar, A.S.; Schintu, N.; Morelli, M. Neuroprotective and AntiInflammatory Effects of the Adenosine A2A Receptor Antagonist ST1535 in a MPTP Mouse Model of Parkinson's Disease. Synapse 2011, 65, 181-188, https://doi.org/10.1002/syn.20833.

92. Bartoccini, F.; Cabri, W.; Celona, D.; Minetti, P.; Piersanti, G.; Tarzia, G. Direct B-Alkyl Suzuki-Miyaura Cross-Coupling of 2-Halopurines. Practical Synthesis of ST1535, a Potent Adenosine A 2A Receptor Antagonist. J. Org. Chem. 2010, 75, 5398-5401, https://doi.org/10.1021/jo101027h.

93. Park, A.; Stacy, M. Istradefylline for the Treatment of Parkinson's Disease. Expert Opin. Pharmacother. 2012, 13, 111-114, https://doi.org/10.1517/14656566.2012.643869.

94. Berk, B.; Akgün, H.; Erol, K.; Sirmagül, B.; Gao, Z.G.; Jacobson, K.A. New 8-Substituted Xanthiene Derivatives as Potent Bronchodilators. Farmaco 2005, 60, 974-980, https://doi.org/10.1016/j.farmac.2005.08.011.

95. Zhao, D.; Wang, W.; Yang, F.; Lan, J.; Yang, L.; Gao, G.; You, J. Copper-Catalyzed Direct c Arylation of Heterocycles with Aryl Bromides: Discovery of Fluorescent Core Frameworks. Angew. Chemie - Int. Ed. 2009, 48, 3296-3300, https://doi.org/10.1002/anie.200900413.

96. Fabian, M.A.; Biggs, W.H.; Treiber, D.K.; Atteridge, C.E.; Azimioara, M.D.; Benedetti, M.G.; Carter, T.A.; Ciceri, P.; Edeen, P.T.; Floyd, M.; et al. A Small Molecule-Kinase Interaction Map for Clinical Kinase Inhibitors. Nat. Biotechnol. 2005, 23, 329-336, https://doi.org/10.1038/nbt1068.

97. Kim, D.; Jun, H.; Lee, H.; Hong, S.S.; Hong, S. Development of New Fluorescent Xanthines as Kinase Inhibitors. Org. Lett. 2010, 12, 1212-1215, https://doi.org/10.1021/ol100011n.

98. Mitsuya, H.; Weinhold, K.J.; Furman, P.A.; St Clair, M.H.; Lehrman, S.N.; Gallo, R.C.; Bolognesi, D.; Barry, D.W.; Broder, S. 3'-Azido-3'-Deoxythymidine (BW A509U): An Antiviral Agent That Inhibits the Infectivity and Cytopathic Effect of Human T-Lymphotropic Virus Type III/Lymphadenopathy-Associated Virus in vitro. Proc. Natl. Acad. Sci. U. S. A. 1985, 82, 7096-7100, https://doi.org/10.1073/pnas.82.20.7096.

99. Herdewijn, P; Balzarini, J; De Clercq, E; Pauwels, R; Baba, M; Broder, S; Vanderhaeghe, H. 3'-substituted 2',3'-dideoxynucleoside analogues as potential anti-HIV (HTLV-III/LAV) agents. J Med Chem. 1987, 30, 1270-1278, https://doi.org/10.1021/jm00391a003.

100.Crimmins, M.T.; King, B.W. An Efficient Asymmetric Approach to Carbocyclic Nucleosides: Asymmetric Synthesis of 1592U89, a Potent Inhibitor of HIV Reverse Transcriptase. J. Org. Chem. 1996, 61, 4192-4193, https://doi.org/10.1021/jo960708p.

101.Silvestri, R.; Artico, M.; La Regina, G.; De Martino, G.; La Colla, M.; Loddo, R.; La Colla, P. Anti-HIV-1 Activity of Pyrryl Aryl Sulfone (PAS) Derivatives: Synthesis and SAR Studies of Novel Esters and Amides at the Position 2 of the Pyrrole Nucleus. Farmaco 2004, 59, 201-210, https://doi.org/10.1016/j.farmac.2003.11.004.

102.Pandey, V.K.; Gupta, V.D.; Upadhyay, M.; Upadhyay, M.; Singh, V.K.; Tandon, M. Synthesis, Characterization and Biological Activity of 1,3,4-Substituted 2-Azetidinones. Indian J. Chem. - Sect. B Org. Med. Chem. 2005, 44, 158-162, https://doi.org/10.1002/chin.200519116.

103.Rizzo, R.C.; Tirado-Rives, J.; Jorgensen, W.L. Estimation of Binding Affinities for HEPT and Nevirapine 
Analogues with HIV-1 Reverse Transcriptase via Monte Carlo Simulations. J. Med. Chem. 2001, 44, 145154, https://doi.org/10.1021/jm000255n.

104.Vlieghe, P.; Bihel, F.; Clerc, T.; Pannecouque, C.; Witvrouw, M.; De Clercq, E.; Salles, J.P.; Chermann, J.C.; Kraus, J.L. New 3'-Azido-3'-Deoxythymidin-5'-Yl O-( $\omega$-Hydroxyalkyl) Carbonate Prodrugs: Synthesis and Anti-HIV Evaluation. J. Med. Chem. 2001, 44, 777-786, https://doi.org/10.1021/jm001033s.

105. Starnes, M.C.; Cheng, Y. Cellular Metabolism of 2',3'-Dideoxycytidine, a Compound Active against Human Immunodeficiency Virus in vitro. J. Biol. Chem. 1987, 262, 988-991, https://doi.org/10.1016/s00219258(19)75738-x.

106.Lak Shin Jeong; Hea Ok Kim; Hyung Ryong Moon; Joon Hee Hong; Su Jeong Yoo; Won Jun Choi; Moon Woo Chun; Lee, C.K. Syntheses and Structure-Activity Relationships of Novel Apio and Thioapio Dideoxydidehydronucleosides as Anti-HCMV Agents. J. Med. Chem. 2001, 44, 806-813, https://doi.org/10.1021/jm000342f.

107.Fredholm, B.B.; IJzerman, A.P.; Jacobson, K.A.; Linden, J.; Müller, C.E. International Union of Basic and Clinical Pharmacology. LXXXI. Nomenclature and Classification of Adenosine Receptors - An Update. Pharmacol. Rev. 2011, 63, 1-34, https://doi.org/10.1124/pr.110.003285.

108.Ryzhov, S.; Goldstein, A.E.; Matafonov, A.; Zeng, D.; Biaggioni, I.; Feoktistov, I. Adenosine-Activated Mast Cells Induce IgE Synthesis by B Lymphocytes: An A 2B -Mediated Process Involving Th2 Cytokines IL-4 and IL-13 with Implications for Asthma. J. Immunol. 2004, 172, 7726-7733, https://doi.org/10.4049/jimmunol.172.12.7726.

109.Zhong, H.; Belardinelli, L.; Maa, T.; Feoktistov, I.; Biaggioni, I.; Zeng, D. A2B Adenosine Receptors Increase Cytokine Release by Bronchial Smooth Muscle Cells. Am. J. Respir. Cell Mol. Biol. 2004, 30, 118125, https://doi.org/10.1165/rcmb.2003-0118OC.

110.Zablocki, J.; Kalla, R.; Perry, T.; Palle, V.; Varkhedkar, V.; Xiao, D.; Piscopio, A.; Maa, T.; Gimbel, A.; Hao, J.; et al. The Discovery of a Selective, High Affinity A2B Adenosine Receptor Antagonist for the Potential Treatment of Asthma. Bioorganic Med. Chem. Lett. 2005, 15, 609-612, https://doi.org/10.1016/j.bmcl.2004.11.044.

111.Schoeder, C.T; Mahardhika, A.B; Drabczyńska, A; Kieć-Kononowicz, K; Müller, C.E. Discovery of Tricyclic Xanthines as Agonists of the Cannabinoid-Activated Orphan G-Protein-Coupled Receptor GPR18. ACS Med Chem Lett. 2020, 11, 2024-2031, https://doi.org/10.1021/acsmedchemlett.0c00208.

112.Rohilla, S.; Bansal, R.; Chauhan, P.; Kachler, S.; Klotz, K.N. A New Series of 1,3-Dimethylxanthine Based Adenosine A2A Receptor Antagonists as a Non-Dopaminergic Treatment of Parkinson's Disease. Curr. Drug Discov. Technol. 2021, 18, https://doi.org/10.2174/1570163817666200827112252.

113.Li, A.-H.; Moro, S.; Melman, N.; Ji, X.-D.; Jacobson, K.A. Structure activity relationships and molecular modeling of 3,5-diacyl-2,4-dialkylpyridine derivatives as selective A3 adenosine receptor antagonists. $J$. Med. Chem. 1998, 41, 3186-3201, https://doi.org/10.1016/j.bmcl.2004.04.099.

114.Cacciari, B.; Pastorin, G.; Spalluto, G. Medicinal Chemistry of A2A Adenosine Receptor Antagonists. Curr. Top. Med. Chem. 2005, 3, 403-411, https://doi.org/10.2174/1568026033392183.

115.Bara-Jimenez, W.; Sherzai, A.; Dimitrova, T.; Favit, A.; Bibbiani, F.; Gillespie, M.; Morris, M.J.; Mouradian, M.M.; Chase, T.N. Adenosine A2A Receptor Antagonist Treatment of Parkinson's Disease. Neurology 2003, 61, 293-296, https://doi.org/10.1212/01.WNL.0000073136.00548.D4.

116.Koga, K.; Kurokawa, M.; Ochi, M.; Nakamura, J.; Kuwana, Y. Adenosine A(2A) Receptor Antagonists KF17837 and KW-6002 Potentiate Rotation Induced by Dopaminergic Drugs in Hemi-Parkinsonian Rats. Eur. J. Pharmacol. 2000, 408, 249-255, https://doi.org/10.1016/S0014-2999(00)00745-7.

117. Yadav, R.; Bansal, R.; Rohilla, S.; Kachler, S.; Klotz, K.N. Synthesis and Pharmacological Characterization of Novel Xanthine Carboxylate Amides as A2A Adenosine Receptor Ligands Exhibiting Bronchospasmolytic Activity. Bioorg. Chem. 2016, 65, 26-37, https://doi.org/10.1016/j.bioorg.2016.01.003.

118.Singh, S.; Ojha, M.; Yadav, D.; Kachler, S.; Klotz, K.N.; Yadav, R. Bronchospasmolytic and Adenosine Binding Activity of 8- (Proline / Pyrazole)- Substituted Xanthine Derivatives. Curr Drug Discov. Tech. 2021; 18, e22092020186181, https://doi.org/10.2174/1570163817666200922121005.

119.Gumber, D.; Yadav, D.; Yadav, R.; Kachler, S.; Klotz, K.N. Bronchospasmolytic Activity and Adenosine Receptor Binding of Some Newer 1,3-Dipropyl-8-Phenyl Substituted Xanthine Derivatives. Chem. Biol. Drug Des. 2020, 95, 600-609, https://doi.org/10.1111/cbdd.13673.

120. Van Der Walt, M.M.; Terre'Blanche, G. 1,3,7-Triethyl-Substituted Xanthines - Possess Nanomolar Affinity for the Adenosine A1 Receptor. Bioorg. Med. Chem. 2015, 23, 6641-6649, https://doi.org/10.1016/j.bmc.2015.09.012. 
121.Monji, F.; Al-Mahmood Siddiquee, A.; Hashemian, F. Can pentoxifylline and similar xanthine derivatives find a niche in COVID-19 therapeutic strategies? A ray of hope in the midst of the pandemic. Eur. J. Pharmacol., 2020, 15, 887, https://doi.org/10.1016/j.ejphar.2020.173561. 